\title{
Gene Therapy in Liver Diseases: State-of-the-Art and Future Perspectives
}

\author{
Kalliopi Domvri ${ }^{1}$, Paul Zarogoulidis ${ }^{1,5}$, Konstantinos Porpodis ${ }^{1}$, Maria Koffa ${ }^{2}$, \\ Maria Lambropoulou ${ }^{3}$, Stylianos Kakolyris ${ }^{4}$, George Kolios ${ }^{5}$, Konstantinos Zarogoulidis ${ }^{1}$, \\ Ekaterini Chatzaki ${ }^{5, *}$
}

\author{
${ }^{I}$ Pulmonary Department-Oncology Unit, " G. Papanikolaou" General Hospital, Aristotle University of Thessaloniki, \\ ${ }^{2}$ Laboratory of Cellular and Molecular Biology, Dept. of Molecular Biology and Genetics, ${ }^{3}$ Laboratory of Histol- \\ ogy/Embryology, ${ }^{4}$ Dept. Oncology, ${ }^{5}$ Laboratory of Pharmacology, Medical School, Democritus University of Thrace, \\ Alexandroupolis, Greece
}

\begin{abstract}
Gene therapy is a fundamentally novel therapeutic approach that involves introducing genetic material into target cells in order to fight or prevent disease. A number of different strategies of gene therapy are tested at experimental and clinical levels, including: a) replacing a mutated gene that causes disease with a healthy copy of the gene, b) inactivating a mutated gene that its improper function causes pathogenesis, c) introducing a new gene coding a therapeutic compound to fight a disease, d) introducing to the target organ an enzyme converting an inactive pro-drug to its cytotoxic metabolite. In gene therapy, the transcriptional machinery of the patient is used to produce the active factor that exerts the intended therapeutic effect, ideally in a permanent, tissue-specific and manageable way. The liver is a major target for gene therapy, presenting inherited metabolic defects of single-gene etiology, but also severe multifactorial pathologies with limited therapeutic options such as hepatocellular carcinoma. The initial promising results from gene therapy strategies in liver diseases were followed by skepticism on the actual clinical value due to specificity, efficacy, toxicity and immune limitations, but are recently re-evaluated due to progress in vector technology and monitoring techniques. The significant amount of experimental data along with the available information from clinical trials are systematically reviewed here and presented per pathological entity. Finally, future perspectives of gene therapy protocols in hepatology are summarized.
\end{abstract}

Keywords: Hepatocellular, gene therapy, liver, metabolic disorder, vector.

\section{INTRODUCTION}

Despite the immense advances in the understanding of the etiology of several liver pathologies at a molecular level, treatment responses remain poor and outcome limited, imposing emerging need for novel therapeutic alternatives. Genetic manipulations for altering gene expression pattern in vivo with therapeutic outcome, known as gene therapy, offer a fundamentally different to pharmacotherapy approach for inherited as well as acquired diseases. Gene therapy, one of the greatest achievements of biomedical science, is based on genetic material transfer techniques in the affected or other relevant tissues, in order to stop the pathogenetic process. Using the host's cell protein synthetic machinery, permanent, tissue specific and controllable changes in gene expression are attempted, that aim to overcome the limitations of classical pharmacology at the level of chemical synthesis and stability of therapeutically useful substances, toxicity, even cost.

Many liver diseases such as hereditary metabolic defects, hepatitis, cirrhosis and primary or metastatic cancer are amenable for gene therapy approaches. The pathology of liver offers theoretically ideal candidates for gene therapy strategies: serious, life-threatening disease, often with known or of single-gene etiology, and limited, ineffective treatment op-

*Address correspondence to this author at the Department of Pharmacology, DUTH, Dragana, Alexandroupolis 68100, Thrace, Greece;

Tel/Fax:+302551030533; E-mail: achatzak@med.duth.gr tions, either surgical or pharmacological. Numerous experimental data have been accumulated, which argue that genetic strategies can be tailored to liver disorders, some of those seen in clinical trials underway. In most studies, the therapeutic nucleic acid is delivered directly or using viral vectors with better transfection efficiency, usually adenoviruses because they exhibit tropism for the liver. Administration can be via intravascular, intra-hepatic or biliary routes. In addition, due to the physiology of the tissue, gene modification of the hepatic parenchyma could turn it into an endogenous laboratory for the production of protein-drugs to treat diseases that do not directly affect its function.

In spite of several approaches, human gene therapy in liver diseases is still in its infancy. The experience to apply protocols in clinical practice that derives from impressive initial results from in vitro and in vivo preclinical studies shows significant expected and unexpected barriers and poses questions about their future. The challenges associated with liver-directed gene therapy are efficient targeting of hepatocytes, stability of the vector genome, and persistent high level expression [1]. In this review, we present the knowledge acquired: what are the strategies developed, the technical possibilities and obstacles, and finally, what seems to be of therapeutic value of gene therapy in liver diseases?

\section{VECTORS AND TREATMENT STRATEGIES}

A gene that is inserted directly into a cell usually does not function. A carrier called vector is often used to intro- 
duce a therapeutic gene into the host's target cells. The most common vector is a virus that has been genetically altered to carry normal human DNA. Target cells such as hepatocytes are infected by the vector, which unloads its genetic material containing the therapeutic human gene into the cell genome. The generation of a functional protein product from the therapeutic gene restores the target cell or the adjunct tissue to a normal state.

Gene therapy vectors can be constructed on the basis of viral or non-viral molecular structures [2]. Integrating RNAviruses and the non-integrating DNA-viruses have been used as viral vectors. The first are subcategorized in a) retroviruses that deliver copies of their RNA genomes that is reverse transcribed to DNA and b) lentiviruses which can deliver large amounts of DNA into the cell and replicate in non-dividing cells. Non-integrating DNA-viruses are subcategorized in: a) Adenoviruses (Ads), with double-stranded DNA genomes; their drawback is respiratory, intestinal and eye infections in humans, b) Adeno-Associated Viruses (AAV) are small, single-stranded DNA viruses; their genetic material can be inserted at a specific site on chromosome 19, and currently, they are among the most frequently used viral vectors for gene therapy and c) Herpes simplex viruses (HSV) are a class of double-stranded viruses that can infect a particular cell type, i.e. neurons.

Adenovirus (Ad) based gene transfer vectors continue to be the platform of choice for an increasing number of clinical trials worldwide. In fact, within the last years, the number of clinical trials that utilize Ad based vectors has increased dramatically, indicating growing enthusiasm for the numerous positive characteristics of this gene transfer platform. However, for the human adenovirus serotype 5 (Ad5), the most frequently used vector prototype; three major limitations have been identified: widespread pre-existing anti-Ad5 immunity in humans [3, 4], an unacceptably large amount of damage to normal non-target tissues, which causes severe toxicity $[5,6]$, and low levels of target-specific gene delivery [7-9]. Several efforts have been made towards diminishing the immune response. These strategies include, modification of viral capsids [10], covalent conjugation of polyethleneglycol (PEG) to Adv [11-14], hydrodynamic injections towards local delivery of low vector doses directly into the liver [15], pretreatment with glucocorticoids, use of lipid bilayer envelopes, and preventing binding to the CAR receptor by masking the adenoviral fiber knob [16-18]. Recent data suggest that combination of immunotherapy with chemotherapy can overcome the inability to give multiple doses, resulting in the boosting of the initial vaccination of the adenovirus [19]. Collectively, these findings indicate modified Ad vector protocols better suited for gene transfer in humans.

In the non-viral vectors for gene delivery the transferred gene is in the form of a plasmid [20] that is on the surface or in the interior of the vector. Such vectors include liposomes [21], molecular conjugates [22], nanoparticles [23], naked DNA [24] and complex DNA [25]. In order for more efficient transfection to be achieved, delivery systems, such as cationic lipids and cationic polymers were used [26]. In this case, the carrier is an artificial lipid sphere (a liposome) with an aqueous core carrying the therapeutic DNA, which is capable of transporting the DNA through the target's cell membrane.

Another way of introducing therapeutic DNA into target cells is by chemically linking the DNA to a molecule that will bind to specific cell receptors where it constructs and is engulfed by the cell membrane and then is passed into the interior of the target cell. This delivery system is however less effective than the other options.

In addition, experiments with the introduction of a $47^{\text {th }}$ chromosome (an artificial, human techno-chromosome) into target cells are being carried out [2]. This chromosome would exist autonomously alongside the standard 46, without affecting their functions or causing any mutations. The construction and the autonomy of this large vector, not only would make it invisible to the body's immune system, but also able to carry substantial amounts of the genetic code. A disadvantage with this method is the difficulty in delivering such a large molecule into the nucleus of a target cell.

Another delivery method is the Sleeping Beauty Transposon System (SBTS), a non-viral gene delivery vehicle found ubiquitously in nature. Transposon-based vectors have the capacity of stable genomic integration and long-lasting expression of transgene constructs in cells [27]. The SBTS consists of the SB Transposon, the SB Transposase - specific to the SB Transposon and a therapeutic gene.

An alternative non-viral option is RNA interference (RNAi), which includes a sequence-specific RNA degradation process in the cytoplasm of eukaryotic cells that is induced by double-stranded RNA (dsRNA). This endogenous regulatory RNA silencing mechanism, which was first described in Caenorhabditis elegans and Drosophila melanogaster, also possesses many similarities with posttranscriptional gene silencing in plants, and the process of quelling in Neurospora crassa [28, 29]. RNAi and related RNA silencing mechanisms are supposed to act as a natural defense against incoming viruses and the expression of transposable elements [30]. Moreover, with the antiviral function of RNAi, there is evidence that RNAi plays an important role in regulating cellular gene expression. The use of RNAi in gene therapy is to disrupt the translation of the faulty mRNA, which is induced by the signal to the signal, to cleave specific unique sequences in the mRNA transcript of the faulty gene. An alternative for gene silencing is the use of specific oligonucleotides antisense to the target gene [2]. In order to overcome the low efficiency of editing genes at their natural location, zinc-finger nucleases (ZFNs) have been constructed which augment this efficacy by making a break in the target site. The ability to modify the DNAbinding specificity of the ZFNs makes them applicable to targeting essentially any desired gene [31]. Despite the fact that the ZFN field is still in its early stages, the potential of ZFNs for gene targeting is indeed successfully used, including mostly animal and human genes [32]. There is some danger, however, that the use of additional fingers will lead to cleavage more sequences that are off target, since a subset may be sufficient to direct binding [31]. Pruett-Miller et al., [33] for example, has shown greater cytotoxicity with a particular pair of 4 -finger ZFNs. 
Finally, another approach is gene-directed enzymeprodrug therapy (GDEPT) or suicide gene therapy, which is comprised of three components; the pro-drug to be activated, the enzyme (usually nonhuman) used for activation, and the delivery system for the corresponding gene [34]. Pro-drugs can be considered as a combination of two major domains; a "trigger" unit that is the substrate for the activating enzyme, and an "effector" unit that is activated or released by this metabolic process, sometimes joined by a definable linker [35]. The most prominent GDEPT therapy has been the use of the herpes simplex type-1 thymidine kinase enzyme (HSV-Tk) in conjunction with a variety of guanosine based pro-drugs, compounds originally developed as antiviral (antiherpes) agents [36-38]. Ganciclovir (GCV; 1a) is the most widely used pro-drug for HSV-Tk, and is well known as an antiviral agent [38]. The cytosine deaminase gene is the next most widely studied for GDEPT.

Tested approaches for DNA delivery in liver diseases include nanoparticles, DNA plasmids with cationic lipids, liposomes and others. AAV vectors offer a more promising alternative, as they are capable of maintaining high levels of hepatic transgene expression for prolonged periods of time, particularly when regulated by tissue-specific enhancers and promoters [39-41]. In addition, significantly higher hepatic transduction efficiencies by administrating relatively low viral dosages has been succeeded, since the discoveries of novel AAV serotypes, such as AAV8 and 9 [42]. Compared to other viral-based gene therapy vectors, AAV vectors have a favorable biosafety profile, because they are less inflammatory and the wild-type virus is nonpathogenic as well as replication-deficient [43]. AAV8 has been shown to be the most efficient vector for liver-directed gene transfer and is currently being evaluated in a clinical trial for treating hemophilia B $[44,45]$ (Table 1).

\section{SEARCH STRATEGY}

We performed an electronic article search through PubMed, Google Scholar, Medscape and Scopus databases, using combinations of the following keywords: Gene Therapy, Lysosomal storage disease, Acute intermittent porphyria, Ornithine transcarbamylase deficiency, $\alpha(1)$-antitrypsin deficiency, acute liver failure, PompeDisease, Tyrosinemia, Crigler-Najjar, Hepatitis, Cirrhosis, and hepatocellular carcinoma. All types of articles (randomized controlled trials, clinical observational cohort studies, review articles, case reports) were included. Selected references from identified articles were searched for further consideration.

\section{LYSOSOMAL STORAGE DISEASES (LSDS)}

LSDs are a group of approximately 50 rare inherited metabolic disorders that result from defects in lysosomal function [46]. Being in most cases of single-gene mutation etiology, they present ideal candidates to replacement gene therapy, i.e. introducing a wild type gene, the product of which substitutes the defective or inadequate enzyme. Herein, we examine the prospects of gene therapy in Acute intermittent porphyria, Ornithine transcarbamylase, Wilson's disease, Hurler syndrome, Sly syndrome, Pompe disease, Tyrosinemia type I, $\alpha(1)$-antitrypsin deficiency, CriglerNajjar. Naturally occurring animal homologues of LSDs have been described in all common domestic animals, presenting models with critical role in evaluating the efficacy and safety of gene therapy (Table 2).

\section{ACUTE INTERMITTENT PORPHYRIA}

Acute intermittent porphyria (AIP) is a rare autosomal dominant affecting the biosynthesis of, the oxygen-binding prosthetic group of hemoglobin [47] due to a deficiency of the enzymehydrogymethylbilane (HMB) synthase, usually attributed to a mutation that causes decreased amounts of the enzyme, and to a lesser degree by a mutation that causes decreased activity. Acute intermittent porphyria is the second most common form of porphyria [48]. The acute attacks are currently treated with intravenousheme, but a more continuous therapy is needed, particularly for patients experiencing frequent attacks [49]. To date, several efforts have been made by using non-viral methods, which were unsuccessful, as they were incapable of achieving sufficient HMBsynthase levels due to their poor transfection efficiency in vivo [50]. In addition, although adenoviral vectors resulted in therapeutic HMB-synthase levels in experimental mice, its expression was transient, thus making them impractical for clinical applications [51]. Administration of recombinant adenoviral, AAV8-based andrecombinant AAV (rAAV) vectors in murine models containing the HMB-synthase complementary DNA, resulted in increased levels of hepatic HMB-synthase activity, inhibiting the phenobarbital-induced ALA and PBG accumulation and thus, indicating a potential for future gene therapy[51-53]. Finally, Johansson et al., 2003 and 2002 showed in mammalian cells that non-viral gene delivery encoding HMB-synthase results in high expression of functional enzyme $[54,55]$, suggesting enzymereplacement gene therapy as a feasible proposal.

\section{ORNITHINE TRANSCARBAMYLASE DEFICIENCY}

Ornithine transcarbamylase deficiency (OTCD), the most common of the genetic results in an ineffective form of the enzyme. Urea cycle defects presenting early in life with hyperammonemia remain difficult to treat and commonly necessitate liver transplantation. Gene therapy has the potential to prevent hyperammonemic episodes while awaiting liver transplantation, and possibly also to avert the need for transplantation altogether. Ornithinetranscarbamylase (OTC) deficiency provides an ideal model for the development of liver-targeted gene therapy.

To date, several studies have been performed in OTCdeficient mouse models (i.e. spfash) using adenoviral and more recently rAAV vectors [56-63]. Although a major limitation of this model is the presence of residual OTC enzymatic activity, which confers a mild phenotype without clinically significant hyperammonemia. Initial poor results with early generation adenoviral vectors [60] have reduced cytotoxicity, but have not overcome limitations imposed by considerable intrinsic immunogenicity $[62,63]$. In the only study reported to date using rAAV, treatment of adult OTCdeficient mice was investigated using vectors pseudo- serotyped with type 7, 8, and 9 capsids [61]. Promising metabolic correction was achieved, albeit at high vector doses, and declining therapeutic efficacy was observed beyond 250 days. The type 8 capsid proved most effective although the 
Table 1. Studies for Gene Therapy in Liver Cancer using Viral Vectors

\begin{tabular}{|c|c|c|c|c|c|c|c|}
\hline Author & $\begin{array}{c}\text { Cell line-Animal } \\
\text { Model }\end{array}$ & Viral Vector & Transfer gene & Combination & Overall & Application & Refs \\
\hline Xu et al., 2011 & mice & $\begin{array}{l}\text { onco- } \\
\text { lytic adenovirus }\end{array}$ & HCCS1 & - & improved & theurapeutic & 178 \\
\hline Kanai et al., 1997 & HuH-7, HLF & rAAV & $C D$ & - & improved & theurapeutic & 180 \\
\hline Gan et al., 2008 & mice & $\begin{array}{c}\text { oncolytic adenovi- } \\
\text { rus }\end{array}$ & HCCS1 & - & improved & theurapeutic & 161 \\
\hline Wei et al., 2011 & HCC cell lines & $\begin{array}{c}\text { onco- } \\
\text { lytic adenovirus }\end{array}$ & SOCS3, TNF & - & improved & theurapeutic & 162 \\
\hline Xue et al., 2010 & $\begin{array}{l}\text { HepG2, Hep3B, } \\
\text { MHCC97L, L02 }\end{array}$ & $\begin{array}{c}\text { oncolytic adenovi- } \\
\text { rus }\end{array}$ & $M D A-7$ & - & improved & theurapeutic & 163 \\
\hline $\begin{array}{c}\text { Takahashi et al., } \\
2002\end{array}$ & $\begin{array}{l}\text { HuH7, HepG2, } \\
\text { PLC/PRF/5 (P5) }\end{array}$ & rAAVs & $E 1 A-13 S$ & - & improved & theurapeutic & 179 \\
\hline Sagawa et al., 2008 & Hep3B & Adenovirus & p53 & - & improved & theurapeutic & 165 \\
\hline Guo et al., 2001 & $\begin{array}{l}\mathrm{PLC} / \mathrm{PRF} / 5 \\
\mathrm{PLC} / \mathrm{PRF} / 5\end{array}$ & rAAV & p53 & - & improved & theurapeutic & 187 \\
\hline Chen et al., 2011 & Hep3B & rAAV2 & $p 53$ & DOX & improved & theurapeutic & 182 \\
\hline Ohashi et al., 2001 & mice & $\begin{array}{c}\text { E1B55k-attenuated } \\
\text { adenovirus }\end{array}$ & $E 1 B$ & - & improved & theurapeutic & 188 \\
\hline Wang et al., 2007 & SMMC-7721 mice & rAAV & $I L-24$ & - & improved & theurapeutic & 186 \\
\hline Song et al., 2008 & HEK-293 cells & rAAVs & NT4p53(N15)An & - & improved & theurapeutic & 185 \\
\hline Xiangji et al., 2011 & HepG2.2.15 cells & $\begin{array}{l}\text { Lentiviral miR- } \\
\text { based system }\end{array}$ & $H B s A g$ & - & improved & theurapeutic & 255 \\
\hline Jin et al., 2011 & L-02, WRL-68 & $\begin{array}{c}\text { oncolytic adenovi- } \\
\text { rus }\end{array}$ & let-7 & - & improved & theurapeutic & 230 \\
\hline Xu et al., 2011 & $\begin{array}{c}\mathrm{HCC} \text { cells in } \mathrm{G} 2 / \mathrm{M} \\
\text { phase }\end{array}$ & adenovirus & MiR-122 & ADM or VCR & improved & theurapeutic & 231 \\
\hline Ma et al., 2010 & $\begin{array}{c}\text { HepG2, Hep3B, } \\
\text { Huh7, PLC/PRF/5 }\end{array}$ & rAAVs & $\operatorname{miR}-122$ & - & improved & theurapeutic & 243 \\
\hline Barajas et al., 2001 & rats & adenovirus & $I L-12$ & - & improved & theurapeutic & 206 \\
\hline Pützer et al., 2001 & woodchucks & adenovirus & IL12/B7.1 & - & improved & theurapeutic & 209 \\
\hline Wei et al., 2011 & HCC cell lines & $\begin{array}{c}\text { oncolytic adenovi- } \\
\text { rus }\end{array}$ & SOCS3, TRAIL & - & improved & theurapeutic & 162 \\
\hline Xu et al., 2011 & $\begin{array}{c}\text { Cancer and normal } \\
\text { cell lines }\end{array}$ & $\begin{array}{l}\text { quadruple-regulated } \\
\text { oncolytic adenovi- } \\
\text { rus }\end{array}$ & HCCS1 & - & improved & theurapeutic & 178 \\
\hline Lam et al., 2007 & HCC cells & HSV-1 & $\begin{array}{c}\text { chimeric Gal4/NF- } \\
Y A\end{array}$ & - & improved & theurapeutic & 167 \\
\hline Argnani et al., 2011 & mice & HSV-1 & $\begin{array}{l}\text { luciferase reporter } \\
\text { gene }\end{array}$ & - & improved & theurapeutic & 171 \\
\hline Foka et al., 2010 & HCC cell lines & HSV-1 & $\begin{array}{l}\text { luciferase reporter } \\
\text { gene }\end{array}$ & & - & $\begin{array}{l}\text { Promoter } \\
\text { ident/tion }\end{array}$ & 168 \\
\hline Sia et al., 2011 & $\begin{array}{l}\mathrm{HCC} \text { and non-HCC } \\
\text { cell lines }\end{array}$ & HSV-1 & $\begin{array}{l}\text { luciferase reporter } \\
\text { gene, }(y C D) \text { genes }\end{array}$ & $\begin{array}{c}\text { yeast yCD -FC5-FC } \\
\text { prodrug }\end{array}$ & improved & theurapeutic & 170 \\
\hline
\end{tabular}


(Table 1) contd....

\begin{tabular}{|c|c|c|c|c|c|c|c|}
\hline Author & $\begin{array}{c}\text { Cell line-Animal } \\
\text { Model }\end{array}$ & Viral Vector & Transfer gene & Combination & Overall & Application & Refs \\
\hline Song et al., 2011 & HCC cell lines & HSV- G207 & diploid ICP6 & - & improved & theurapeutic & 172 \\
\hline Wills et al., 1995 & $\begin{array}{l}\text { HCC cell lines and } \\
\text { mice }\end{array}$ & adenovirus & $T k$ & $\begin{array}{l}\text { ganciclovir treat- } \\
\text { ment }\end{array}$ & improved & theurapeutic & 173 \\
\hline Iwai et al., 2002 & mice & $\begin{array}{l}\text { EBV-based plas- } \\
\text { mid vector }\end{array}$ & $H S V-1 T k$ & PEI & improved & theurapeutic & 174 \\
\hline Harada et al., 2000 & HCC cells lines & $\begin{array}{l}\text { EBV-based plas- } \\
\text { mid vectors }\end{array}$ & $\beta$-gal & $\begin{array}{l}\text { EBV/lipoplex- } \\
\text { PAAD }\end{array}$ & improved & theurapeutic & 175 \\
\hline Chen et al., 2011 & HCC cell lines & $\begin{array}{c}\text { oncolytic adenovi- } \\
\text { rus }\end{array}$ & p53 & - & improved & theurapeutic & 182 \\
\hline Inoue et al., 2004 & HCC cell lines & adenovirus & p53 & $\begin{array}{l}\text { TRAIL-induced } \\
\text { apoptosis }\end{array}$ & improved & theurapeutic & 183 \\
\hline Yang et al., 2010 & 40 Patients & adenovirus & p53 & $\begin{array}{l}\text { fractionated stereo- } \\
\text { tactic radiotherapy }\end{array}$ & efficient & Clinical trial & 190 \\
\hline Tian et al., 2009 & 1 Patient & adenovirus & p53 & $\begin{array}{l}\text { Oxaliplatin, chemo- } \\
\text { therapy and TACE }\end{array}$ & efficient & Clinical trial & 191 \\
\hline Tian et al., 2009 & 46 Patients & rAAV & p53 & TACE & efficient & $\begin{array}{l}\text { pilot phase II } \\
\text { trial }\end{array}$ & 192 \\
\hline Habib et al., 2002 & 10 Patients & $\begin{array}{l}\text { E1B-deleted ade- } \\
\text { novirus (d11520) }\end{array}$ & p53 & - & NSD & Clinical trial & 189 \\
\hline Guan et al., 2005 & 1 Patient & adenovirus & p53 & TACE & efficient & Clinical trial & 193 \\
\hline
\end{tabular}

HCCS1; hepatocellular carcinoma suppressor 1, CD; cytosine deaminase gene, SOCS3; suppressor of cytokine signaling 3, TNF; tumor necrosis factor, HSV-Tk; Doxorubicine; DOX, herpes simplex virus thymidine kinase gene, IL-24; interleukin-24, HBsAg; surface antigen of hepatitis B virus, IL-12; interleukin-12, MiR; microRNA, TRAIL; tumor necrosis factor-related apoptosis-inducing ligand, HSV-1; herpes simplex virus type 1, Adriamycin; ADM, vincristine ;VCR, TK; thymidine kinase, EBV; epstein barr virus, HSV-1 Tk; herpes simplex virus-1 thymidine kinase, polyethylenimine, PEI; EBV/lipoplex; cationic liposome, PAAD; polyamidoamine dendrimer, FC-5; fluorocitosine, TACE; transcatheter arterial chemoembolization.

Table 2. Gene Therapy Published Studies for Metabolic Liver Diseases and Hepatitis

\begin{tabular}{|c|c|c|c|c|c|c|c|}
\hline Author & Disease Target & $\begin{array}{c}\text { Therapeutic } \\
\text { molecule }\end{array}$ & $\begin{array}{l}\text { Animal } \\
\text { Model }\end{array}$ & Vector & Delivery system & Overall & Refs \\
\hline Johansson et al., 2003 & $\begin{array}{l}\text { Acute intermit- } \\
\text { tent porphyria }\end{array}$ & $P B G D$ & murine & $\begin{array}{c}\text { Non viral (naked } \\
\text { DNA) }\end{array}$ & $\begin{array}{l}\text { intravenous or } \\
\text { portal vein } \\
\text { injection }\end{array}$ & $\begin{array}{c}\text { Not } \\
\text { improved }\end{array}$ & 54 \\
\hline Johansson et al., 2004 & $\begin{array}{l}\text { Acute intermit- } \\
\text { tent porphyria }\end{array}$ & $P B G D$ & mice & adenovirus & intravenous & NSD & 50 \\
\hline Unzu et al., 2011 & $\begin{array}{l}\text { Acute intermit- } \\
\text { tent porphyria }\end{array}$ & $P B G D$ & mice & rAAV & $\begin{array}{c}\text { Phenobarbital } \\
\text { injections }\end{array}$ & improved & 53 \\
\hline Johansson et al., 2003 & $\begin{array}{l}\text { Acute intermit- } \\
\text { tent porphyria }\end{array}$ & $P B G D$ & mammalian cells & non-viral & intravenous & improved & 55 \\
\hline Johansson et al., 2004 & $\begin{array}{l}\text { Acute intermit- } \\
\text { tent porphyria }\end{array}$ & $P B G D$ & mammalian cells & non-viral & intravenous & improved & 51 \\
\hline Cunningham et al., 2011 & $\begin{array}{l}\text { Ornithine tran- } \\
\text { scarbamylase }\end{array}$ & OTC & mice & rAAV & intraperitoneal & improved & 56 \\
\hline Kiwaki et al., 1996 & $\begin{array}{l}\text { Ornithine tran- } \\
\text { scarbamylase }\end{array}$ & OTC & mice & rAAV & intravenous & improved & 60 \\
\hline
\end{tabular}


(Table 2) contd...

\begin{tabular}{|c|c|c|c|c|c|c|c|}
\hline Author & Disease Target & $\begin{array}{c}\text { Therapeutic } \\
\text { molecule }\end{array}$ & $\begin{array}{l}\text { Animal } \\
\text { Model }\end{array}$ & Vector & Delivery system & Overall & Refs \\
\hline Mian et al., 2004 & $\begin{array}{l}\text { Ornithine tran- } \\
\text { scarbamylase }\end{array}$ & OTC & mice & adenovirus & tail-vein injection & improved & 62 \\
\hline Brunetti-Pierri et al., 2008 & $\begin{array}{l}\text { Ornithine tran- } \\
\text { scarbamylase }\end{array}$ & OTC & mice & adenovirus & tail-vein injection & improved & 63 \\
\hline Moscioni et al., 2006 & $\begin{array}{l}\text { Ornithine tran- } \\
\text { scarbamylase }\end{array}$ & OTC & mice & AAV & $\begin{array}{l}\text { portal vein injec- } \\
\text { tion }\end{array}$ & improved & 61 \\
\hline Wang et al., 2012 & $\begin{array}{l}\text { Ornithine tran- } \\
\text { scarbamylase }\end{array}$ & OTC & mice & AAV8 & intravenous & improved & 58 \\
\hline Wang et al., 2011 & $\begin{array}{l}\text { Ornithine tran- } \\
\text { scarbamylase }\end{array}$ & OTC & mice & AAV & intravenous & improved & 59 \\
\hline Roybal et al., 2011 & Wilson's disease & $A T P 7 B$ & murine & lentivirus & prenatal & improved & 68 \\
\hline Zhang et al., 2011 & Wilson's disease & $A T P 7 B$ & Human iPSCs & lentivirus & Ex vivo & improved & 69 \\
\hline Merle et al., 2006 & Wilson's disease & $A T P 7 B$ & rat & lentivirus & $\begin{array}{c}\text { systemic applica- } \\
\text { tion }\end{array}$ & improved & 70 \\
\hline Ha-Hao et al., 2002 & Wilson's disease & ATP7B & rat & adenovirus & tail-vein injection & improved & 71 \\
\hline Liu et al., 2005 & $\begin{array}{l}\text { Hurler syn- } \\
\text { drome }\end{array}$ & $I D U A$ & mice & retroviral & intravenous & improved & 78 \\
\hline Ma et al., 2007 & $\begin{array}{l}\text { Hurler syn- } \\
\text { drome }\end{array}$ & $I D U \mathrm{~A}$ & mice & retroviral & intravenous & improved & 80 \\
\hline Metcalf et al., 2009 & $\begin{array}{l}\text { Hurler syn- } \\
\text { drome }\end{array}$ & $I D U A$ & mice & retroviral & intravenous & improved & 81 \\
\hline Kobayashi et al., 2005 & $\begin{array}{l}\text { Hurler syn- } \\
\text { drome }\end{array}$ & $I D U A$ & mice & lentiviral & intravenous & improved & 86 \\
\hline Hartung et al., 2004 & $\begin{array}{l}\text { Hurler syn- } \\
\text { drome }\end{array}$ & $I D U A$ & mice & rAAV & intravenous & improved & 85 \\
\hline Ponder et al., 2006 & $\begin{array}{l}\text { Hurler syn- } \\
\text { drome }\end{array}$ & $I D U A$ & Cats, dogs & retroviral & intravenous & improved & 82 \\
\hline Traas et al., 2007 & $\begin{array}{l}\text { Hurler syn- } \\
\text { drome }\end{array}$ & $I D U A$ & Canine dogs & retroviral & intravenous & improved & 83 \\
\hline Herati et al., 2008 & $\begin{array}{l}\text { Hurler syn- } \\
\text { drome }\end{array}$ & $I D U A$ & $\operatorname{dog} s$ & retroviral & intravenous & improved & 84 \\
\hline Di Domenico et al., 2006 & $\begin{array}{l}\text { Hurler syn- } \\
\text { drome }\end{array}$ & $I D U A$ & mice & retroviral & intravenous & improved & 87 \\
\hline Ma et al., 2007 & $\begin{array}{l}\text { Hurler syn- } \\
\text { drome }\end{array}$ & $I D U A$ & mice & retroviral & intravenous & improved & 80 \\
\hline Daly et al., 2001 & Sly syndrome & $G U S$ & mice & AAV & intravenous & improved & 93 \\
\hline Elliger et al., 2002 & Sly syndrome & $G U S$ & mice & AAV & $\begin{array}{c}\text { intrathecal, intra- } \\
\text { venous }\end{array}$ & improved & 94 \\
\hline Cotugno et al., 2011 & Sly syndrome & GUS & feline & AAV & intravascular & improved & 91 \\
\hline Ponder et al., 2002 & Sly syndrome & $G U S$ & $\operatorname{dog} s$ & retroviral & intravenous & improved & 96 \\
\hline Xu et al., 2002 & Sly syndrome & $G U S$ & mice & retroviral & intravenous & improved & 95 \\
\hline Xu et al., 2002 & Sly syndrome & $G U S$ & $\operatorname{dog} s$ & retroviral & intravenous & improved & 97 \\
\hline
\end{tabular}


(Table 2) contd....

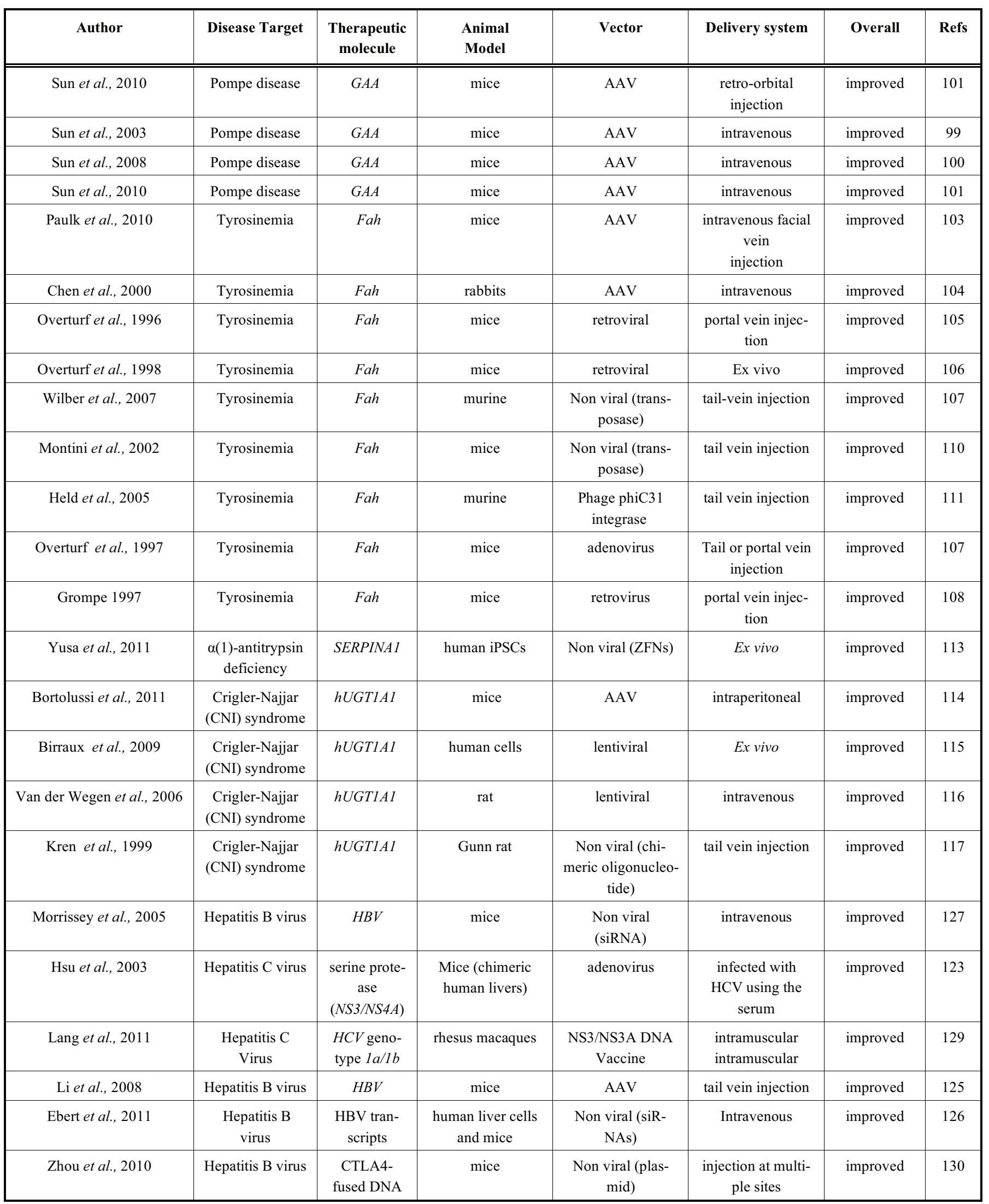

NSD; not significant difference, PBGD; porphobilinogen deaminase, AAV; adeno-associated virus, rAAV; recombinant adeno- associated virus, iPSCs; human induced pluripotent stem cells, IDUA; gene responsible for the production of iduronidase enzyme protein production (mapped to the $4 \mathrm{p} 16.3$ site on chromosome 4 , GUS; beta-glucuronidase reporter gene, Fah; furmarylacetoacetate gene, ZFNs; zinc finger nucleases, A1AT or SERPINA1; a(1)-antitrypsin gene, 1A1(hUGT1A1); uridine disphoshate glucuronyltransferase 
maximal OTC activities achieved were sub-physiological. Finally, Cunningham et al., [64] showed that AAV2/8mediated transgene delivery is an extremely powerful tool for life-long correction of OTC deficiency in the adult mouse, but is less robust in neonatal mice, where substantial loss of transgene expression occurs during liver growth.

\section{WILSON'S DISEASE}

Wilson's disease is a genetic disease caused by mutations in the $A T P 7 B$ gene, which is responsible for the expression of a liver transporter protein that coordinates copper export into bile and blood [65]. Current medical treatments including chelating agents and zinc salts are not effective in all Wilson disease patients. Liver transplantation is the alternative option [65-67]. To date, few gene therapy efforts have been tested in animal models of Wilson disease. In the murine model, adenoviral and lentiviral gene transfer studies have shown that viral gene transfer is therapeutically effective and can reverse clinical symptoms [68-71]. However, these approaches were limited by a more or less transient transgene expression. Other researchers demonstrated a selfinactivating lentiviral vector that expresses codon optimized$A T P 7 B$ or treatment with the chaperone drug curcumin showing reduction of the functional defect in vitro [69]. In conclusion, there is still a long way to go until gene therapy can be used for safe treatment of Wilson disease in humans.

\section{MUCOPOLYSACCHARIDOSES}

Mucopolysaccharidoses (MPSs) form a group of more than 40 caused by the absence or malfunction of enzymes. Here we provide information for three of them; MPS I, MPS VII and MPS IV concerning results from gene therapy approaches.

\section{MPS I}

Mucopolysaccharidosis type I (MPS IH; Hurler syndrome or $\alpha$-L-iduronidase deficiency) is a rare genetic disorder caused by mutations in the IDUA gene, resulting the deficiency of $\alpha$-L-iduronidase enzyme activity and intracellular accumulation of glycosaminoglycans (GAGs) [72]. The low or absent lysosomal enzyme activity leads to this accumulation which is essential to the GAG catabolism, and results in systemic impairment of organs and tissues. A characteristic skeletal phenotype is one of the many clinical manifestations in Hurler disease. Available treatments for patients with MPS I currently consist of hematopoietic stem cell transplantation [73] or enzyme replacement therapy [74]. Gene therapy as a promising alternative to existing treatments for MPS I, has improved clinical manifestations of the disease in a variety of animal models [75]. There are several recent reports which designed viral and non-viral vectors for Hurler syndrome. For example, Aronovich et al., [76, 77] demonstrated the reversion of MPS I phenotypein adult mice, using therapeutic SB transposon plasmids encoding human IDUA.

However, most of the approaches include viral vectors. In particular, neonatal administration of $\gamma$-retroviral vectors $(\gamma$ RV) [78-81], lentiviral vectors, or AAV vectors expressing the IDUA gene have prevented many aspects of MPS I dis- ease in mice, while $\gamma$-RV have been effective in dogs and cats [82-85]. Administration of a $\gamma-\mathrm{RV} 7$ or a lentiviral vector $[86,87]$ to adult mice without immunosuppression, had no therapeutic effect. Ma et al., [80] showed improvement in MPSI symtopatology in adult mice, after retroviral vectormediated gene therapy with immunomodulation.

\section{MPS VI}

Mucopolysaccharidosis type VI (MPS-VI) is an autosomal recessive lysosomal storage disorder caused by the deficiency of $\mathrm{N}$-acetylgalactosamine-4-sulfatase (4S; or $A R S B)$. Mutations in the $4 S$ gene are responsible for $4 \mathrm{~S}$ deficiency, which leads to the intralysosomal storage of partially degraded glycosaminoglycans, dermatan sulfate, and chondroitin 4-sulfate [88]. The disorder shows a wide spectrum of symptoms from slowly to rapidly progressing forms. The characteristic skeletal dysplasia includes short stature, dysostosis multiplex and degenerative joint disease. Moreover, before enzyme replacement therapy (ERT) with galsulfase (Naglazyme), clinical management was limited to supportive care and hematopoietic stem cell transplantation. Galsulfase is now widely available and is a specific therapy providing improved endurance with an acceptable safety profile.

Few reports have demonstrated the utility of viral vectors in MPS VI. Byers et al., [89], indicated that the lentiviral vector can be used to deliver $4 S$ to a range of joint tissues in vitro and efficiently transduce synovial cells to express betagalactosidase in vivo. A study by Ho et al., [90], supported the utility of AAV as a vector for the treatment of retinal pigment epithelium (RPE) cells of feline MPS VI. Finally, Cotugno et al., [91] showed that intravascular administration of AAV in MPS VI cats, represents a promising therapeutic strategy for MPS VI patients.

\section{SLY SYNDROME}

Another example of treating LSDs with gene therapy is MPS type VII or Sly syndrome. Here, the gene of interest encodes $\beta$-glucuronidase (GUS), whose absence or functional defectiveness causes a buildup of glycosaminoglycan (GAG) storage granules within the lysosomes of most cell types [92]. In humans, this disease is characterized by mental retardation, abnormal bone development, distorted features, and organ malfunctions leading to organ failure and early death. Fortunately, Sly syndrome is rare; however, because a great deal is known about GUS and because there are animal models of this disease, Sly syndrome has become a paradigm for the study of lysosomal storage diseases in general and for gene therapy in particular. Furthermore, complete regulation of expression is not necessary, as has been found that overexpression does not cause problems, and if $2 \%$ of normal levels are restored the abnormal phenotype is reversed. These features make this disease an ideal target for the application of gene technology.

Attempts for gene therapy in MPS VII in animal models involve intravenous injection of vectors derived from AAV, adenovirus, retrovirus or a plasmid. Daly et al., [93] reported that AAV-mediated gene transfer in the neonatal period can lead to the prevention of many of the clinical symptoms as- 
sociated with MPS VII in the murine model. Indeed, therapeutic levels of enzyme persist for at least 1 year following a single intravenous injection of virus in neonatal MPS VII mice. The level and distribution of GUSB expression were sufficient to prevent many clinical symptoms over the life of the animal. By adding coding sequences for secretion (Igא) and uptake (HIV-1 TAT) signals to the GUS gene delivered by AAV, and treated mice both intrathecally and intravenously as newborns, Elliger et al., [94] have increased the GUS enzyme levels in more tissues and have improved the health of the mice so much that they were able to breed [94]. Several more recent reports attempted gene therapy for MPS VII in animal models; one approach involves neonatal i.v. injection of a $\gamma$-retroviral vector expressing $\beta$-glucuronidase, which results in transduction of liver cells and secretion of enzyme into blood in significant levels [95-97]. In conclusion, gene therapy holds great promise for providing a longlasting therapeutic effect for MPS VII if safety and higher expression levels issues can be resolved [75].

\section{POMPE DISEASE}

The Glycogen storage disease type II (GSD II) is another LSD, also known as acid maltase deficiency or Pompe disease. It is caused by mutations in the gene of acid alphaglucosidase (GAA), the enzyme responsible for breaking down glycogen into glucose, causing absence or significantly reduction in enzyme levels. Classic infantile-onset Pompe disease may be apparent in utero but it more often presents in the first month of life with hypotonia, generalized muscle weakness, cardiomegaly and hypertrophic cardiomyopathy, feeding difficulties, failure to thrive, respiratory distress, and hearing loss. The existing available treatment reverses cardiac muscle damage and enhances life expectancy in those with the infantile form of the disease, but is less effective in skeletal muscle.

Some recent approaches include gene therapy by using viral vectors. Koeberl et al., [98] reported that immune tolerance to the transgene could be achieved by liver-specific expression with AAV vectors by enhancing the efficacy. Sun et al., [99-101] made several efforts in murine Pompe disease by administrating AVV vectors with promising results. Despite the presence of immune responses, the successful development of gene therapy in mice is a fact, which indicates that curative therapy for Pompe disease may become available in the foreseeable future.

\section{TYROSINEMIA}

Tyrosinemia is caused by a shortage of enzyme fumarylacetoacetate hydrolase (FAH) [102]. The usual manifestations appear in the first few months of life and include failure to gain weight and grow at the expected rate (failure to thrive), diarrhea, vomiting, yellowing of the skin and whites of the eyes (jaundice), cabbage-like odor, and increased tendency to bleed (particularly nosebleeds). Tyrosinemia can lead to liver and kidney failure, problems affecting the nervous system, and an increased risk of liver cancer. Toxic metabolites such as fumarylacetoacetate accumulate in hepatocytes and renal proximal tubules, causing death in a cellautonomous manner [102].
Paulk et al., [103] demonstrated stable hepatic gene repair in both adult and neonatal mice with AAV-FAH serotypes 2 and 8, showing that AAV-mediated gene repair is feasible in vivo and can functionally correct enzymedeficiency consequences. In a study by Chen et al., [104] a murine model for hereditary tyrosinemia was used to evaluate in vivo gene therapy with AAV vectors expressing FAH. Results reported that after 9 months, vector-treated animals showed benign hepatomas, whereas in untreated animals areas of marked dysplasia were present within hepatomas. Furthermore, Overturf et al., [105, 106] demonstrated in vivo and ex vivo successful effects in murine models by administrating adenoviral vector [107] but in therapeutic trials, Grompe et al., showed that 2/3 treated animals developed hepatocarcinoma after 1 year retroviral gene transfer [108]. Wilber et al., [109] tested the use of transposase-encoding RNA plus transposon DNA for correction of murine FAH deficiency. The authors concluded that transposase-encoding messenger RNA (mRNA) can be used to mediate stable nonviral gene therapy, resulting in complete phenotypic correction. Using the same strategy, Montini et al., [110] demonstrated long-lasting correction of the FAH-deficiency phenotype.

Finally, Held et al., [111] used Phage phiC31 integrase, which is a site-specific recombinase that mediates efficient integration of circular extra-chromosomal DNA into the host genome. They used this integrase system to transfer the $F A H$ gene into the liver of mice affected with hereditary tyrosinemia, suggesting that it may have utility in many gene therapy settings. Overall, several gene therapy strategies have shown therapeutic potential for tyrosinemia, which still needs to be proven in humans.

\section{$\alpha(1)$-ANTITRYPSIN DEFICIENCY}

Alpha 1-antitrypsin deficiency ( $\alpha 1$-antitrypsin deficiency, A1AD or simply Alpha-1) is a recessive caused by defective production of (A1AT also known as SERPINA1). This miss expression leads to decreased A1AT activity in lungs, and deposition of excessive abnormal A1AT protein in liver cells [112]. The enzyme deficiency causes pulmonary emphysema, while $10 \%$ of patients develop cirrhosis due to accumulation of defective folded protein. The administration of the enzyme gene with adenovirus could reverse the lung damage in mice and baboons, while for liver cirrhosis gene repair is essential.

Yusa et al., [113] showed that a combination of zinc finger nucleases (ZFNs) and piggyBac technology in human induced pluripotent stem cells and achieved biallelic correction of a point mutation (Glu342Lys) in the A1AT. Genetic correction of human induced pluripotent stem cells restored the structure and function of A1AT in subsequently derived liver cells in vitro and in vivo. This approach is significantly more efficient than any other gene-targeting technology that is currently available and prevents contamination of the host genome with residual non-human sequences.

\section{CRIGLER-NAJJAR}

Crigler-Najjar syndrome is characterized by unconjugated hyperbilirubinemia resulting from an autosomal recessive inherited deficiency of hepatic UDP-glucuronosyl- 
transferase (UGT) 1A1 activity. The enzyme is essential for glucuronidation and biliary excretion of bilirubin, and its absence can be fatal. Bortolussi et al., [114] by using AAV9mediated gene transfer, showed the rescue of bilirubininduced neonatal lethality in a mouse model of CriglerNajjar syndrome. In addition, Birraux et al., [115] and Wegen et al., [116] showed successful treatment of CriglerNajjar syndrome, by administrating the human UGT1Al with lentiviral vectors in mice and rat animal models respectively. Kren et al., [117] showed permanent correction of the UGT1A1 genetic defect in Gunn rat liver with site-specific replacement of the absent $\mathrm{G}$ residue at nucleotide 1206 by using an RNA/DNA oligonucleotide designed to promote endogenous repair of genomic DNA. However, none of these protocols have so far been translated into a clinical trial [118].

\section{HEPATITIS C AND B}

Hepatitis $\mathrm{C}$ virus (HCV) infection is a serious global health problem that affects 180 million people worldwide [119]. Hepatitis C virus is a major cause of chronic liver diseases which can lead to permanent liver damage, hepatocellular carcinoma and death [120]. The present available treatment with interferon plus ribavirin, has limited benefits due to adverse side effects such as anemia, depression and "flu-like" symptoms. Hence, the development of a new treatment is crucial, and gene therapy is on target. In this case, the goal of treatment is to resolve the viral potential for infection, cirrhosis and liver failure and not develop liver cancer.

An option for HCV eradication is RNA which is an attractive target for RNAi, as the single positive-stranded viral transcript functions both as genomic RNA and a replication template, and also because of its localization in the infected liver, an organ that can be readily targeted by nucleic acid molecules and viral vectors. Several reports demonstrated potent RNAi activity against HCV in sub-genomic replicon and fully infectious HCV particles [121]. A review of Ashfaq et al., [122] concluded that combination of siRNA against virus and host genes will be a better option to treat $\mathrm{HCV}$.

Alternatively, suicide gene therapy is based on administration of genes encoding cytotoxic agents that have been modified to be expressed only in cells infected by the virus of hepatitis. For example, a chimeric molecule that when cut by a protease of $\mathrm{HCV}$ releases BID, an agent that induces apoptosis in infected cells. Another report demonstrated that modified apoptotic molecule (BID) reduces hepatitis $\mathrm{C}$ virus infection in mice with chimeric human livers [123].

Hepatitis B is also an infectious illness caused by (HBV) which infects the liver of hominoidea, including humans, and causes hepatitis [124]. Interferon-alpha2 (IFNalpha2) is routinely used for anti-hepatitis B virus (HBV) treatment. However, as in $\mathrm{HCV}$, the therapeutic efficiency is unsatisfactory too. Liz et al., [125] managed to decrease the level of viral DNA over 30 -fold for several weeks by testing a single dose of vector-delivered IFNalphal for its anti-HBV effects. Another recent report combined gene silencing by using $5^{\prime}$ Triphosphorylated siRNAs control replication of hepatitis B virus with induction of IFN in the liver [126]. As in HCV, there is also a report demostrating that siRNA may be a clinically viable therapeutic approach for HBV [127].

An alternative therapeutic approach that combines gene silencing with induction of IFN in the liver was demonstrated by Ebert et al., [126]. He reported that this combination in $\mathrm{HBV}$-infected primary human hepatocytes and in HBV transgenic mice controlled replication of HBV efficiently. In general, it is well-recognized that a combination of gene therapy antiviral treatment and immunomodulation is essential to achieve a sustained control of $\mathrm{HBV}$ and $\mathrm{HCV}$ infection.

Another way for activation anti-viral immunity, which may have therapeutic and preventive clinical value, is DNAvaccines that induce the synthesis of viral antigens of hepatitis B or C - surface and central. There are plenty of advantages for such a vaccine; the easy production and storage since the DNA is much more stable than the respective protein antigens, the potential for epidermal (particle-mediated epidermal delivery, PMED), the reduction of contamination, the possibility of parallel immunization with different genes, and the use of DNA induces cytotoxic immune response. This response is induced because the antigen is expressed intracellularly just as in cells infected with actual virus and thus immunity is more effective and more permanent. Clinical trials of DNA vaccines given intramuscularly, or transdermal method of gene-gun-show absence of toxicity and development of effective immunity [128]. The parallel administration of interferon genes has also been suggested as a treatment regimen. Numerous studies have suggested that an effective hepatitis $\mathrm{C}$ virus (HCV) vaccine must induce a strong T helper 1 (Th1) T cell response. Lang et al., [129] used the rhesus macaque vaccination model in assessing HCV DNA vaccine-induced $\mathrm{T}$ cell responses and presented a useful tool in the evaluation of immune responses induced by $\mathrm{HCV}$ immunogens. Finally, the increased immunogenicity of DNA vaccines can be achieved by the fusion of specific antigens to extracellular domain of cytotoxic-T-lymphocyteassociated antigen 4 (CTLA4) which represents a promising approach. Zhou et al., [130] evaluated this interesting approach for its enhancement on HBV-specific immune responses and its antiviral effects in HBV transgenic mice. Thus, the CTLA4-fused DNA vaccine led to breakdown of immune tolerance to viral infection in HBV transgenic mice, which might be used as a therapeutic vaccine in HBV infection.

\section{LIVER CIRRHOSIS}

Liver cirrhosis is the irreversible end result of fibrous scarring and hepatocellular regeneration, characterized by diffuse disorganization of the normal hepatic structure of regenerative nodules and fibrotic tissue. It is associated with prominent morbidity and mortality, and is induced by many factors, including chronic hepatitis virus infections, alcohol drinking and drug abuse. The treatment aims at limiting hepatocyte destruction and decreasing fibrosis. Hepatocyte growth factor (HGF), originally identified and cloned as a potent mitogen for hepatocytes, shows mitogenic, motogenic and morphogenic activities for a wide variety of cells. Moreover, HGF plays an essential part in the development and regeneration of the liver, and shows anti-apoptotic activ- 
ity in hepatocytes. In a rat model of lethal liver cirrhosis produced by dimethylnitrosamine administration, repeated transfections of the human HGF gene into skeletal muscles induced a high plasma level of human as well as enodogenous rat $\mathrm{HGF}$, and tyrosine phosphorylation of the cMet/HGF receptor. Transduction with the HGF gene also suppressed the increase of transforming growth factor-beta1 (TGF- 1 1), which plays an essential part in the progression of liver cirrhosis, inhibited fibrogenesis and hepatocyte apoptosis, and produced the complete resolution of fibrosis in the cirrhotic liver, thereby improving the survival rate of rats with this severe illness. Thus, HGF gene therapy may be potentially useful for the treatment of patients with liver cirrhosis, which is otherwise fatal and untreatable by conventional therapy [131].

TGF- $\beta 1$ and its signaling pathway also present targets for gene therapy. One approach is to deliver dominant negative gene for defective receptor in order to dimerize with the wild type receptor and inactivate it, or alternatively hyperexpression of Smad7, a signal transduction element that antagonizes secondary TGF- $\beta 1$ messengers. The inhibition of TGF- $\beta 1$ has been demonstrated by several authors either by using adenoviral vectors [132-135], recombinant plasmid [136] or siRNA [137] in vivo, resulting in the prevention of liver fibrosis. The second approach which includes the hyper-expression of Smad7, totally blocks TGF- $\beta 1$ signal transduction. Indeed, several studies demonstrated that adenovirus-mediated overexpression of Smad7 in rats [138-141] resulted in significant inhibition of fibrosis. Besides, TGF- $\beta 1$ is also a key mediator of liver fibrosis [142-144]. Arias et al., $[145,146]$ demonstrated that adenoviral expression of a TGF- $\beta 1$ antisense mRNA is effective in preventing liver fibrosis in bile-duct ligated rats. Furthermore, Yeom et al., [147] constructed a siRNA targeting Smad3 which prevented the activity of TGF- $\beta 1$.

In conclusion, gene therapy may be potentially useful for the treatment of patients with liver cirrhosis, which however remains to be proven in human.

\section{LIVER CANCER}

Liver cancer is one of the most common malignant tumors worldwide and the third leading cause of cancer-related death. Because of its high malignancy and fast progression, most high-grade patients have tumors that are unresectable. Plenty of pathways are involved in the development of hepatocellular carcinoma (HCC) and are depicted as follows: (a) activation of the Wnt/Frizzled/catenin pathway through mutations in catenin as well as up-regulation of upstream elements, such as Frizzled receptor, (b) alteration of the MAPK signaling pathway through HBV or HCV infection, (c) activation of the JAK/STAT pathway through inactivation of JAK-binding proteins, (d) inactivation of the tumor suppressor gene $p 53$ through gene mutation and posttranscriptional interaction with viral proteins as well as oxidative stress, (e) alteration of the tumor suppressor retinoblastoma $(\mathrm{pRb}$ pathway) and p16INK4 genes through mutations or promoter methylation, and (f) alteration of the TGF- $\beta$ pathway [148]. Furthermore, many HCC-related oncogenes, including $A F P, R A S, c-F O S, c-J U N, R H O, T G F-a, H G F, C e r b B 2$, HER-2,HER-2/neu, NEU, NGL, MDM2, MMP, and IGF, have been found. The abnormal expression of these genes with regard to uncontrolled cell proliferation results ultimately in carcinogenesis [149].

The best curative options for the treatment of liver cancer are the surgical resection and liver transplantation. Chemotherapy and radiotherapy are also applied, however with major drawbacks such as the high frequency of tumor recurrence, metastasis and generally low responses. Moreover, recent experimental treatment approaches, including hormonal therapy, biologic, biochemical therapy [150-154], and molecular targeted therapy [155-158], are still needed to be verified in clinical application. Thus, there is an urgent need to develop novel treatments for recurrent and advanced HCC. Gene therapy suggests a novel and promising approach for liver cancer via a variety of gene transfer strategies aiming to the treatment of patients with primary and secondary liver tumors, including gene directed enzyme/prodrug therapy, inhibition of oncogenes and restoration of tumor-suppressor genes, immunotherapy, anti-angiogenesis and virotherapy (Fig. 1). Some of these strategies have reached early clinical development with diverting success.

\section{INHIBITION OF ONCOGENES AND RESTORATION OF TUMOR-SUPPRESSOR GENES BY ONCOLYTIC AND OTHER VIRUSES}

The strategy of "Cancer Targeting Gene-Viro-Therapy" (CTGVT) was developed in 2001 [159] and has increased expectations in the treatment of cancer. It combines the advantages of gene therapy and oncolytic viral therapy. Oncolytic adenoviruses can replicate themselves in cancer cells and lyse the carcinoma, whereas they are very inefficient in normal cells. Tumor suppressor genes can replicate together with oncolytic viral vectors, thereby greatly enhancing the ability to induce cancer cell death [160]. In published studies, oncolytic adenovirus-mediated gene therapy has produced good results in targeting cancer cells. However, safety and efficacy, the two most important aspects in cancer therapy, remain serious challenges.

Gan et al., [161] inserted the novel tumor suppressor gene hepatocellular carcinoma suppressor 1 (HCCS1) into an oncolytic adenovirus and exhibited a dramatic inhibitory effect on cancer cells in vitro and in vivo, leading to a complete regression of $50 \%$ of established tumor xenografts in nude mice. However, the antitumor efficacy of oncolytic adenoviruses on human hepatocellular carcinoma (HCC) cells was compromised due to low expression of the adenovirus serotype 5 (Ad5) receptor on the target cells.

Wei et al., [162] incorporated two therapeutic genes, suppressor of cytokine signaling 3 (SOCS3) and tumor necrosis factor-related apoptosis-inducing ligand (TRAIL) into a double-regulated oncolytic adenovirus vector. Their results exhibited potent antitumor activity in carcinoplacental antigen $\alpha$-fetoprotein (AFP)-positive HCC cell lines both in vitro and in vivo. Another report also tested the oncolytic adenovirus vector, enhancing the antitumor activity in HCC cell lines with similar results [163].

Moreover, to specifically target liver malignant cells, cancer gene therapy needs to combine highly selective gene delivery with highly specific gene expression. Towards this 


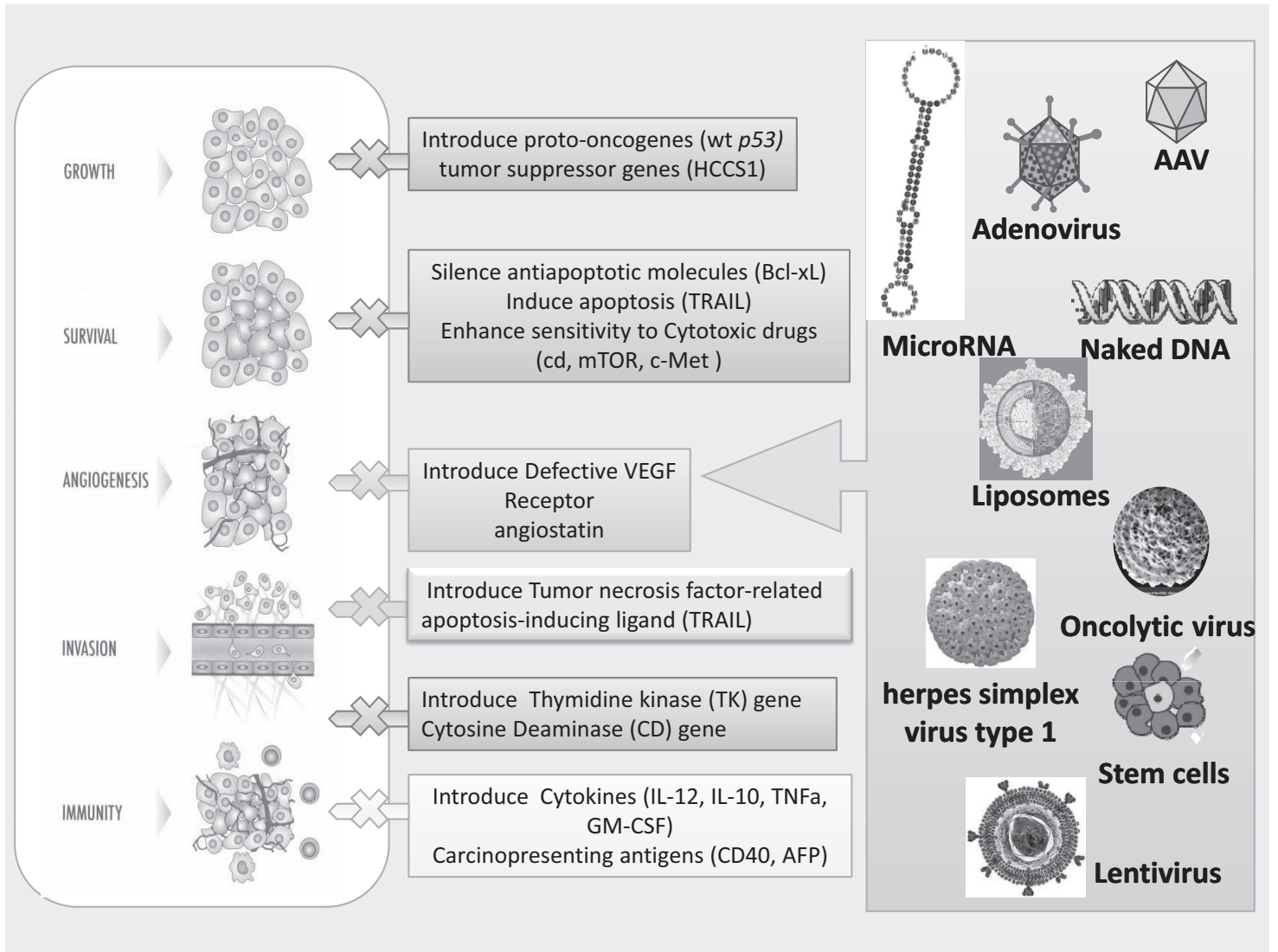

Fig. (1). Targets for gene therapy in liver cancer.

target, several approaches have been made [164-169]. Herpes virus simplex type-1 (HSV-1) is one of the most promising viral platforms for transferring therapeutic genes and the development of oncolytic vectors that can target, multiply in, and eradicate hepatoma cells via their lytic cycle. More specifically, Foka et al., [168] identified and experimentally characterized novel hepatoma-specific promoters, which were valuable for cancer-specific gene therapy, by using HSV-1 vectors. Sia et al., [170] used as a viral vector the HSV-1 amplicon in HCC and non-HCC cell lines in vitro and in vivo with promising results. Several other reports characterized different kinds of HSV-1 vectors as platforms for virotherapy against liver cancer [167, 168, 171-173].

Researchers have also used Epstein-Barr virus (EBV)based plasmid vectors and demonstrated suicide gene therapy in vitro and in vivo suggesting efficient expression of the gene [174-176]. More specifically, these reports demonstrated in mice and in HCC cells that (EBV)-based plasmid vectors coupled with polyamidoamine dendrimer or polyethylenimine-mediated is a very useful tool in suicide gene therapy of cancer.

The gene of the carcinoplacental antigen $\alpha$-fetoprotein $(A F P)$ is overexpressed in HCC which makes it also a target of gene therapy. Kanai et al., [177] demonstrated that replication defective recombinant adenoviral vectors, containing the human AFP promoter/enhancer, can be used to express the Escherichia coli cytosine deaminase (CD) gene
(AdAFPCD) and the $\beta$-galactosidase gene (AdAF-PlacZ) in AFP-producing HCC cell lines. Hai-Neng Xu et al., [178] showed reduced toxicity and excellent anti-liver cancer efficacy by using quadruple-regulated adenoviruses carrying an AFP promoter-controlled HCCS1 gene both in vitro and in vivo. Other reports also used adenoviral vectors for AFP delivery in hepatocellular carcinoma cells in vitro or in vivo in animal models showing promising strategies for cancer specific therapy which may have clinical use in the future [179, $180]$.

Abnormalities of $p 53$ are also considered a predisposition factor for hepatocarcinogenesis as $p 53$ is frequently mutated in HCC [181]. p53 gene transfer has been proposed as a potential therapeutic option for treatment of HCC. Some researchers used adenoviral-mediated transfer or oncolytic adenovirus by expressing $p 53$ fiber chimeric oncolytic adenovirus in combination with $p 53$ expression, promising a safe anticancer agent for the treatment of $\operatorname{HCC}[182,183]$. Furthermore, Gu et al., [184] studied the effect of adenovirus (Ad)-p53 gene therapy on HCC in a rabbit model and concluded that trans-arterial Ad-p53 gene therapy can reduce tumor growth of HCC. In a series of published studies data were presented of a constructed recombinant adenovirus vectors by replacing E1 region by exogenous DNA, demonstrating induction of HCC cell cytotoxicity and apoptosis in vitro and in vivo [185-188]. Habib et al., [189] attempted a clinical trial of E1B-deleted adenovirus (d11520) gene therapy for HCC with no effective antitumor results. This study 
showed that the adenovirus was well tolerated, but did not seem to offer significant tumor control. Several clinical studies of (Ad)-p53 combined with fractionated stereotactic radiotherapy or with chemotherapy and trans-catheter arterial chemo-embolization for HCC were conducted and presented promising results [190-193]. Recombinant adenoviral vector expressing wt-p53 (Ad-p53) [209] yield a relatively low degree of acute toxicity, compared to other commonly used gene transfer vectors such as adenovirus and retrovirus, recombinant AAV serotype 2 (rAAV2) [214] has shown promising results in human clinical trials. Significant enhancement in the gene transfer efficiency is needed, however, for HCC applications.

\section{IMMUNOTHERAPY}

Cancer immunotherapy can be defined as the techniques used to eliminate malignant tumors through mechanisms through immune system responses [194, 195]. The goal of cancer immunotherapy is to direct against tumors extremely potent immune responses such as those naturally occurring against microbial antigens, and subsequently apply these results to human cancer diseases [196]. Cancer represents almost $70 \%$ of the clinical trials conducted in patients and $25 \%$ of these studies consisted in the application of cytokine genes [196]. Two main approaches have been used in gene transfer of immunostimulatory cytokines (e.g. IL-2, IL-4, IL6, IL-7; IL-12, INF- $\gamma$, TNF- $\alpha$, GM-CSF) [144]: i) vectors expressing cytokines/chemokines/costimulatory molecules injected directly into tumor lesions, or ii) transduction of tumor /dendritic cells ex vivo with vectors expressing cytokines/costimulatory molecules [196]. Several reports demonstrated the potential usefulness of IL-12 gene transfer for liver tumors treatment in animal models, mostly by using adenovirus vectors [197-211]. Recent studies showed that the combination of cytokines with anti-angiogenic gene therapies achieved better antitumor effects on large tumors [162].

The other immunotherapy strategy includes the use of oncolytic viruses for cytokine gene delivery which also offers a promising treatment of liver tumors [189, 212-215]. As discussed earlier, these vectors are considered quite effective, associated with higher infectious rate and prolonged expression. However, gene therapy with oncolytic viruses in hepatoceccular carcinoma induced also immune responses, expression of heterologous genes in unwanted tissues or cells that could shut down the function gene expression [216].

\section{microRNA}

One of the most promising anticancer therapies involves the use of microRNA (miRNA), the efficacy of which mainly depends on the efficiency of the delivery system [217, 218]. miRNAs are a class of short endogenous RNAs. There are about 1000 known miRNA today. A lot of findings suggest the involvement of miRNAs in the pathogenesis of HCC, i.e. the irregular expression of miRNAs [219-227] and the association with the clinical outcome of cancer patients [228, 229]. miRNAs may function as oncogenes while others act as tumor suppressors; studies in animal models treated with miRNAs or in combination with chemotherapy showed promising results [230-251] (Table 3 ). The identification of
miRNA function involved in liver cancer has provided an important knowledge regarding miRNA tumor associated gene interactions and revealed many potential therapeutic targets.

\section{CONTROL OF TUMOR MICROENVIRONMENT}

The microenvironment of the HCC is composed of nontumor cells and their stroma, with the stroma having been implicated in the regulation of tumor growth, metastatic potential and outcome following therapy. Niess et al., [252] used engineered mesenchymal stem cells (MSCs) as therapeutic vehicles for the treatment of HCC. They concluded that stem cell-mediated introduction of suicide genes into the tumor followed by pro-drug administration was effective towards liver cancer [252].

\section{ACUTE LIVER FAILURE}

Acute liver failure (ALF) is a life-threatening medical emergency and occurs when the liver rapidly looses its function within a short period. ALF is mainly caused by viral infections, primarily HBV (hepatitis B virus), HAV (hepatitis A virus) and HEV (hepatitis E virus) in the East and developing countries, such as China and India [253, 254]. In contrast, the majority of ALF is resulted from a drug overdose in the West and developed countries. ALF can also be developed secondarily due to a variety of causes such as infection with non-hepatotropic viruses, including cytomegalovirus, Epstein-Barr virus, adenovirus and hemorrhagic fever virus, vascular diseases, such as Budd-Chiari syndrome and venoocclusive disease, metabolic diseases, such as Wilson's syndrome, Reye's syndrome, acute fatty liver of pregnancy and galactosemia, and idiosyncratic drug/toxin reactions [255]. Currently, the orthotopic liver transplantation (OLT) is the "Gold Standard" therapy for the disease. However, due to the limited availability of donor organs and rapid progression of the disease, the mortality of ALF remains high. Therefore, it is imperative to develop novel therapeutic reagents for ALF. Gene therapy by delivering a target gene to the patients appears to be a promising approach for the treatment of ALF. Besides, the asialoglycoprotein receptor (ASGP-R) is uniquely and highly expressed on hepatocytes, offering a mechanism for glycoprotein-mediated hepatocytespecific delivery [256]. In contrast, the major drawback for ALF gene therapy is that multiple factors contribute for its development, such as apoptosis, necrosis, inflammation and liver regeneration.

Therefore, gene therapy for treating ALF is still in its infancy. Several studies report successful development of gene therapy for ALF in animals, mostly mice [257-267]. The main non viral vectors used in theses references are siRNA antisense oligonucleotides and Zinc-finger nucleases (ZFNs). Currently, there is no large-scale clinical trial to test a specific gene. However, gene therapy holds great promise in inhibition of the disease progression, benefiting the ALF patients. Potentially, gene therapy may become an alternative or at least complement to OLT for intervention of ALF patients. Zhu et al., [268] proposed targeting $f g l 2$ for inhibiting necrosis, together with Fas to reduce apoptosis and HGF to promote liver regeneration; this multitarget approach could synergistically block the progression of ALF. 
Table 3. MicroRNA (miR) for Hepatocellular Carcinoma (HCC)

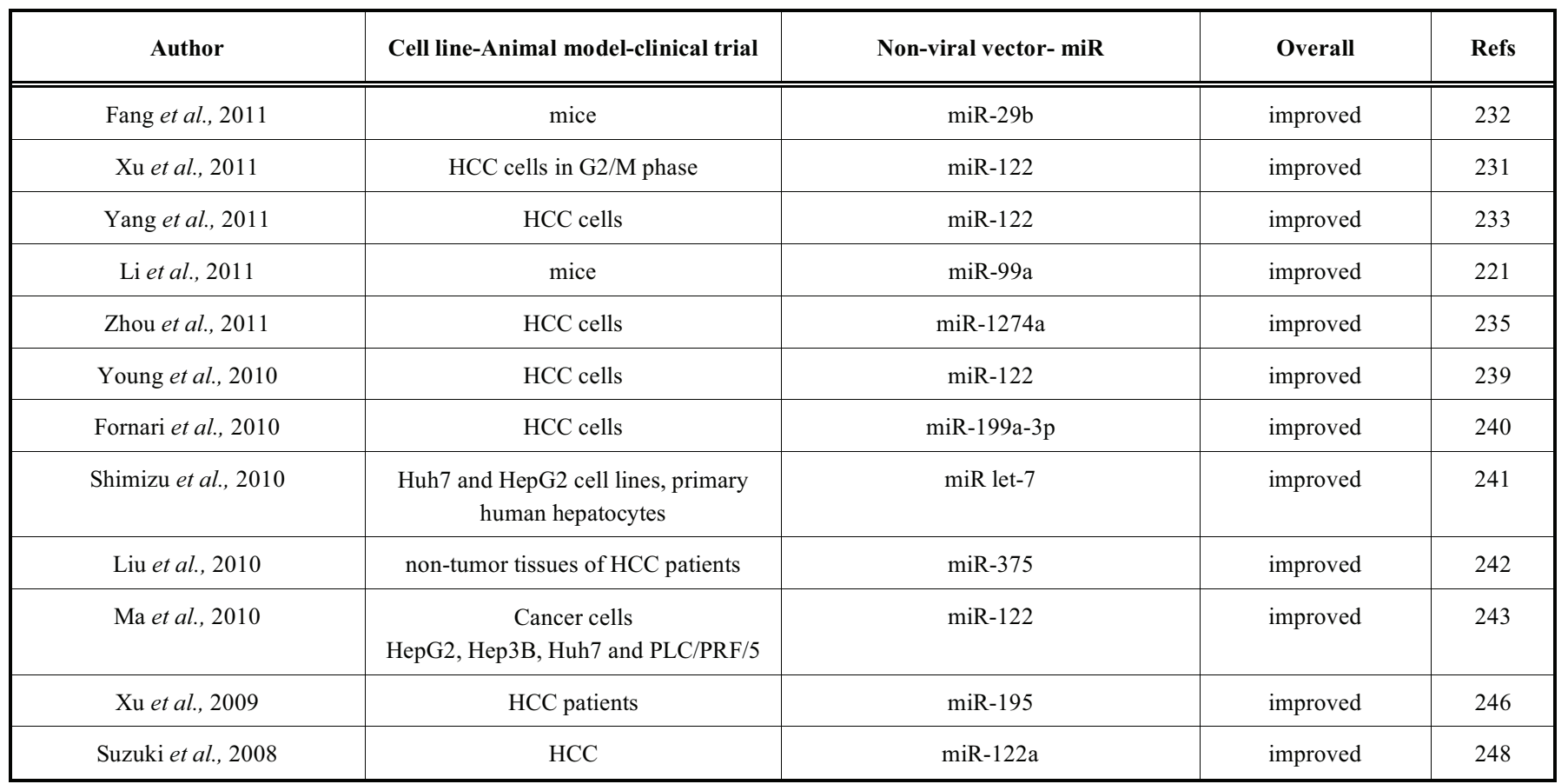

\section{CONCLUSIONS}

In this review, we have focused on the ongoing development of gene therapy in liver diseases. We summarized the different strategies that have been explored to improve the efficacy of gene therapy in these diseases. During the past decade, gene therapy has offered plenty of therapeutic options. Unfortunately, a clear therapeutic effect for most of the liver diseases has not yet been achieved. Several reasons could explain these results; the neutralization of the virus by the immune system, severe toxicity, and low levels of targetspecific gene delivery. Despite several efforts in clinical research trials the effectiveness and clinical utility were undermined also by several limitations, such as insufficient delivery, intravascular administration and short-lived transgene expression. Still, gene therapy for liver cancer is moving towards clinical application with promising results and especially when the virus is administered in combination with existing chemotherapy and radiation therapy. Hopefully, the ever growing knowledge on molecular pathways and the construction of improved and more effective vectors will shed new light on the right path in order to ensure the best clinical efficacy.

Nonviral vectors are simpler, safer, and less expensive than viruses and offer very large carrying capacities. Transfection efficiency can be increased by associating the DNA with a carrier, such as a liposome or a polymer, or through the use of a physical stimulus, such as an electric pulse (electroporation). Nonviral gene delivery (transfection) remains much less efficient than viral gene delivery (transduction) and this remains a barrier to its wider use. Recent progress in vector technology and imaging techniques, allowing in vivo assessment of gene expression, will facilitate the development of clinical applications of gene therapy. Although only a small number of patients were treated, it becomes apparent that more effective vectors are needed to achieve a useful clinical impact. Overall, the numerous experimental strategies addressing gene therapy efficacy in liver diseases need to be evaluated in clinical trials and may offer successful therapeutic alternatives.

\section{CONFLICT OF INTEREST}

The author(s) confirm that this article content has no conflicts of interest.

\section{ACKNOWLEDGEMENTS}

Declared none.

\section{REFERENCES}

[1] Sands SA, Morilak DA. Expression of alpha1D adrenergic receptor messenger RNA in oxytocin- and corticotropin-releasing hormonesynthesizing neurons in the rat paraventricular nucleus. Neuroscience 1999; 91(2):639-49.

[2] Mammen B, Ramakrishnan T, Sudhakar U. Principles of gene therapy. Indian J Dent Res 2007; 18(4):196-200.

[3] Chirmule N, Propert K, Magosin S, Qian Y, Qian R, Wilson J. Immune responses to adenovirus and adeno-associated virus in humans. Gene Ther 1999; 6(9):1574-83.

[4] Vogels MT, Sweep CG, Hermus AR, van der Meer JW. Interleukin-1-induced nonspecific resistance to bacterial infection in mice is not mediated by glucocorticosteroids. Antimicrob Agents Chemother 1992; 36(12):2785-9.

[5] Lieber A, He CY, Meuse L, Schowalter D, Kirillova I, Winther B, et al. The role of Kupffer cell activation and viral gene expression in early liver toxicity after infusion of recombinant adenovirus vectors. J Virol 1997; 71(11):8798-807.

[6] Muruve DA, Barnes MJ, Stillman IE, Libermann TA. Adenoviral gene therapy leads to rapid induction of multiple chemokines and acute neutrophil-dependent hepatic injury in vivo. Hum Gene Ther 1999; 10(6):965-76. 
[7] Dmitriev I, Krasnykh V, Miller CR, Wang M, Kashentseva E, Mikheeva $\mathrm{G}$, et $\mathrm{al}$. An adenovirus vector with genetically modified fibers demonstrates expanded tropism via utilization of a coxsackievirus and adenovirus receptor-independent cell entry mechanism. J Virol 1998; 72(12):9706-13.

[8] Hasenburg A, Fischer DC, Tong XW, Rojas-Martinez A, Kaufman RH, Ramzy I, et al. Adenovirus-mediated thymidine kinase gene therapy for recurrent ovarian cancer: expression of coxsackieadenovirus receptor and integrins alphavbeta 3 and alphavbeta5. J Soc Gynecol Investig 2002; 9(3):174-80.

[9] Hemminki A, Belousova N, Zinn KR, Liu B, Wang M, Chaudhuri $\mathrm{TR}$, et al. An adenovirus with enhanced infectivity mediates molecular chemotherapy of ovarian cancer cells and allows imaging of gene expression Mol Ther 2001; 4(3):223-31.

[10] Glasgow JN, Mikheeva G, Krasnykh V, Curiel DT. A strategy for adenovirus vector targeting with a secreted single chain antibody. PLoS One 2009; 4(12):e8355.

[11] Eto Y, Yoshioka Y, Ishida T, Yao X, Morishige T, Narimatsu S, et $a l$. Optimized PEGylated adenovirus vector reduces the anti-vector humoral immune response against adenovirus and induces a therapeutic effect against metastatic lung cancer. Biol Pharm Bull 2010; 33(9):1540-4

[12] Eto Y, Yoshioka Y, Mukai Y, Okada N, Nakagawa S. Development of PEGylated adenovirus vector with targeting ligand. Int J Pharm 2008; 354(1-2):3-8.

[13] Hofherr SE, Shashkova EV, Weaver EA, Khare R, Barry MA. Modification of adenoviral vectors with polyethylene glycol modulates in vivo tissue tropism and gene expression. Mol Ther 2008; 16(7):1276-82.

[14] Kreppel F, Kochanek S. Modification of adenovirus gene transfer vectors with synthetic polymers: a scientific review and technical guide. Mol Ther 2008; 16(1):16-29.

[15] Brunetti-Pierri N, Stapleton GE, Palmer DJ, Zuo Y, Mane VP, Finegold MJ, et al. Pseudo-hydrodynamic delivery of helperdependent adenoviral vectors into non-human primates for liverdirected gene therapy. Mol Ther 2007; 15(4):732-40.

[16] Seregin SS, Appledorn DM, McBride AJ, Schuldt NJ, Aldhamen YA, Voss $\mathrm{T}$, et al. Transient pretreatment with glucocorticoid ablates innate toxicity of systemically delivered adenoviral vectors without reducing efficacy. Mol Ther 2009; 17(4):685-96.

[17] Peruzzi D, Dharmapuri S, Cirillo A, Bruni BE, Nicosia A, Cortese $\mathrm{R}$, et al. A novel chimpanzee serotype-based adenoviral vector as delivery tool for cancer vaccines. Vaccine 2009; 27(9):1293-300.

[18] Sack BK, Herzog RW. Evading the immune response upon in vivo gene therapy with viral vectors. Curr Opin Mol Ther 2009; 11(5):493-503.

[19] Fridlender ZG, Sun J, Singhal S, Kapoor V, Cheng G, Suzuki E, et al. Chemotherapy delivered after viral immunogene therapy augments antitumor efficacy via multiple immune-mediated mechanisms. Mol Ther 2010; 18(11):1947-59.

[20] Noireaux V, Libchaber A. A vesicle bioreactor as a step toward an artificial cell assembly. Proc Natl Acad Sci U S A 2004; 101(51):17669-74.

[21] Miyazaki M, Obata Y, Abe K, Furusu A, Koji T, Tabata Y, et al. Gene transfer using nonviral delivery systems. Perit Dial Int 2006; 26(6):633-40.

[22] Kim JW, Lee HS. Tumor targeting by doxorubicin-RGD-4C peptide conjugate in an orthotopic mouse hepatoma model. Int $\mathrm{J}$ Mol Med 2004; 14(4):529-35.

[23] Barraud L, Merle P, Soma E, Lefrancois L, Guerret S, Chevallier $\mathrm{M}$, et al. Increase of doxorubicin sensitivity by doxorubicin-loading into nanoparticles for hepatocellular carcinoma cells in vitro and in vivo. J Hepatol 2005; 42(5):736-43.

[24] Tada M, Hatano E, Taura K, Nitta T, Koizumi N, Ikai I, et al. High volume hydrodynamic injection of plasmid DNA via the hepatic artery results in a high level of gene expression in rat hepatocellular carcinoma induced by diethylnitrosamine. J Gene Med 2006;8(8):1018-26.

[25] Meyer F, Ball V, Schaaf P, Voegel JC, Ogier J. Polyplexembedding in polyelectrolyte multilayers for gene delivery. Biochim Biophys Acta 2006; 1758(3):419-22.

[26] Kodama K, Katayama Y, Shoji Y, Nakashima H. The features and shortcomings for gene delivery of current non-viral carriers. Curr Med Chem 2006; 13(18):2155-61.
[27] Ivics Z, Izsvak Z. Transposons for gene therapy!. Curr Gene Ther 2006; 6(5):593-607.

[28] Hannon GJ. RNA interference. Nature 2002; 418(6894):244-51.

[29] Sharp PA. RNA interference--2001. Genes Dev 2001; 15(5):48590.

[30] Nathan RA, Bronsky EA, Fireman P, Grossman J, LaForce CF, Lemanske RF, Jr., et al. Once daily fluticasone propionate aqueous nasal spray is an effective treatment for seasonal allergic rhinitis. Ann Allergy 1991; 67(3):332-8.

[31] Carroll D. Progress and prospects: zinc-finger nucleases as gene therapy agents. Gene Ther 2008; 15(22):1463-8.

[32] Porteus MH. Mammalian gene targeting with designed zinc finger nucleases. Mol Ther 2006; 13(2):438-46.

[33] Pruett-Miller SM, Connelly JP, Maeder ML, Joung JK, Porteus $\mathrm{MH}$. Comparison of zinc finger nucleases for use in gene targeting in mammalian cells. Mol Ther 2008; 16(4):707-17.

[34] Anderson WF. Gene therapy scores against cancer. Nat Med 2000; 6(8):862-3.

[35] Denny WA, Wilson WR, Hay MP. Recent developments in the design of bioreductive drugs. Br J Cancer Suppl 1996; 27:S32-8.

[36] Wilson WR, Pullen SM, Hogg A, Helsby NA, Hicks KO, Denny WA. Quantitation of bystander effects in nitroreductase suicide gene therapy using three-dimensional cell cultures. Cancer Res 2002; 62(5):1425-32.

[37] De Clercq E. Guanosine analogues as anti-herpesvirus agents. Nucleosides Nucleotides Nucleic Acids 2000; 19(10-12):1531-41.

[38] De Clercq E, Andrei G, Snoeck R, De Bolle L, Naesens L, Degreve $\mathrm{B}$, et al. Acyclic/carbocyclic guanosine analogues as antiherpesvirus agents. Nucleosides Nucleotides Nucleic Acids 2001; 20(4-7):271-85.

[39] Mingozzi F, Liu YL, Dobrzynski E, Kaufhold A, Liu JH, Wang Y, et al. Induction of immune tolerance to coagulation factor IX antigen by in vivo hepatic gene transfer. J Clin Invest 2003; 111(9):1347-56.

[40] Nathwani AC, Davidoff AM, Hanawa H, Hu Y, Hoffer FA, Nikanorov A, et al. Sustained high-level expression of human factor IX (hFIX) after liver-targeted delivery of recombinant adeno-associated virus encoding the hFIX gene in rhesus macaques. Blood 2002; 100(5):1662-9.

[41] Ziegler RJ, Lonning SM, Armentano D, Li C, Souza DW, Cherry $\mathrm{M}$, et al. AAV2 vector harboring a liver-restricted promoter facilitates sustained expression of therapeutic levels of alphagalactosidase $\mathrm{A}$ and the induction of immune tolerance in Fabry mice. Mol Ther 2004; 9(2):231-40.

[42] Sarkar DK. Neuroendocrine-immune axis of alcoholics. Alcohol Clin Exp Res 1996; 20(8 Suppl):256A-9A.

[43] Nathwani AC, Davidoff AM, Tuddenham EG. Prospects for gene therapy of haemophilia. Haemophilia 2004; 10(4):309-18.

[44] Nathwani AC, Tuddenham EG, Rangarajan S, Rosales C, McIntosh $\mathrm{J}$, Linch DC, et al. Adenovirus-associated virus vector-mediated gene transfer in hemophilia B. N Engl J Med 2011; 365(25):235765.

[45] Li X, Fu GF, Fan YR, Shi CF, Liu XJ, Xu GX, et al. Potent inhibition of angiogenesis and liver tumor growth by administration of an aerosol containing a transferrin-liposome-endostatin complex. World J Gastroenterol 2003; 9(2):262-6.

[46] Winchester B, Vellodi A, Young E. The molecular basis of lysosomal storage diseases and their treatment. Biochem Soc Trans 2000; 28(2):150-4.

[47] Whatley SD, Roberts AG, Llewellyn DH, Bennett CP, Garrett C, Elder GH. Non-erythroid form of acute intermittent porphyria caused by promoter and frameshift mutations distant from the coding sequence of exon 1 of the HMBS gene. Hum Genet 2000; 107(3):243-8.

[48] Morison WL. Phototherapy and photochemotherapy of skin disease. 3rd ed. Boca Raton: Taylor \& Francis 2005.

[49] Kauppinen R, Timonen K, Mustajoki P. Treatment of the porphyrias. Ann Med 1994; 26(1):31-8.

[50] Johansson A, Nowak G, Moller C, Harper P. Non-viral delivery of the porphobilinogen deaminase cDNA into a mouse model of acute intermittent porphyria. Mol Genet Metab 2004; 82(1):20-6.

[51] Johansson A, Nowak G, Moller C, Blomberg P, Harper P. Adenoviral-mediated expression of porphobilinogen deaminase in 
liver restores the metabolic defect in a mouse model of acute intermittent porphyria. Mol Ther 2004; 10(2):337-43.

[52] Yasuda M, Domaradzki ME, Armentano D, Cheng SH, Bishop DF, Desnick RJ. Acute intermittent porphyria: vector optimization for gene therapy. J Gene Med 2007; 9(9):806-11.

[53] Amado JA, Lopez-Espadas F, Vazquez-Barquero A, Salas E, Riancho JA, Lopez-Cordovilla JJ, et al. Blood levels of cytokines in brain-dead patients: relationship with circulating hormones and acute-phase reactants. Metabolism 1995; 44(6):812-6.

[54] Johansson A, Moller C, Harper P. Correction of the biochemical defect in porphobilinogen deaminase deficient cells by non-viral gene delivery. Mol Cell Biochem 2003; 250(1-2):65-71.

[55] Johansson A, Moller C, Gellerfors P, Harper P. Non-viral mediated gene transfer of porphobilinogen deaminase into mammalian cells. Scand J Clin Lab Invest 2002; 62(2):105-13.

[56] Cunningham SC, Kok CY, Dane AP, Carpenter K, Kizana E, Kuchel PW, et al. Induction and prevention of severe hyperammonemia in the spfash mouse model of ornithine transcarbamylase deficiency using shRNA and rAAV-mediated gene delivery. Mol Ther 2011; 19(5):854-9.

[57] Cunningham SC, Dane AP, Spinoulas A, Logan GJ, Alexander IE. Gene delivery to the juvenile mouse liver using AAV2/8 vectors. Mol Ther 2008; 16(6):1081-8.

[58] Wang L, Morizono H, Lin J, Bell P, Jones D, McMenamin D, et al. Preclinical evaluation of a clinical candidate AAV8 vector for ornithine transcarbamylase (OTC) deficiency reveals functional enzyme from each persisting vector genome. Mol Genet Metab 2012; 105(2):203-11.

[59] Wang L, Wang H, Morizono H, Bell P, Jones D, Lin J, et al. Sustained correction of OTC deficiency in $\operatorname{spf}($ ash) mice using optimized self-complementary AAV2/8 vectors. Gene Ther 2012; 19(4):404-10

[60] Kiwaki K, Kanegae Y, Saito I, Komaki S, Nakamura K, Miyazaki JI, et al. Correction of ornithine transcarbamylase deficiency in adult spf(ash) mice and in OTC-deficient human hepatocytes with recombinant adenoviruses bearing the CAG promoter. Hum Gene Ther 1996; 7(7):821-30

[61] Moscioni D, Morizono H, McCarter RJ, Stern A, Cabrera-Luque J, Hoang A, et al. Long-term correction of ammonia metabolism and prolonged survival in ornithine transcarbamylase-deficient mice following liver-directed treatment with adeno-associated viral vectors. Mol Ther 2006; 14(1):25-33

[62] Mian A, McCormack WM, Jr., Mane V, Kleppe S, Ng P, Finegold $\mathrm{M}$, et al. Long-term correction of ornithine transcarbamylase deficiency by WPRE-mediated overexpression using a helperdependent adenovirus. Mol Ther 2004; 10(3):492-9.

[63] Brunetti-Pierri N, Clarke C, Mane V, Palmer DJ, Lanpher B, Sun $\mathrm{Q}$, et al. Phenotypic correction of ornithine transcarbamylase deficiency using low dose helper-dependent adenoviral vectors. J Gene Med 2008; 10(8):890-6.

[64] Cunningham SC, Spinoulas A, Carpenter KH, Wilcken B, Kuchel $\mathrm{PW}$, Alexander IE. AAV2/8-mediated correction of OTC deficiency is robust in adult but not neonatal $\mathrm{Spf}($ ash) mice. Mol Ther 2009; 17(8):1340-6.

[65] Sauer V, Siaj R, Stoppeler S, Bahde R, Spiegel HU, Kohler G, et al. Repeated transplantation of hepatocytes prevents fulminant hepatitis in a rat model of Wilson's disease. Liver Transpl 2012; 18(2):248-59.

[66] Van den Berghe GH, De Zegher FE. A senescent pattern of pituitary function during critical illness and dopamine treatment. Verh K Acad Geneeskd Belg 1996; 58(4):383-411.

[67] Du C, Fujii Y, Ito M, Harada M, Moriyama E, Shimada R, et al. Dietary polyunsaturated fatty acids suppress acute hepatitis, alter gene expression and prolong survival of female Long-Evans Cinnamon rats, a model of Wilson disease. J Nutr Biochem 2004; 15(5):273-80.

[68] Roybal JL, Endo M, Radu A, Gray L, Todorow CA, Zoltick PW, et al. Early gestational gene transfer with targeted ATP7B expression in the liver improves phenotype in a murine model of Wilson's disease. Gene Ther 2011; doi: 10.1038/gt.2011.186.

[69] Zhang S, Chen S, Li W, Guo X, Zhao P, Xu J, et al. Rescue of ATP7B function in hepatocyte-like cells from Wilson's disease induced pluripotent stem cells using gene therapy or the chaperone drug curcumin. Hum Mol Genet 2011; 20(16):3176-87.
[70] Merle U, Encke J, Tuma S, Volkmann M, Naldini L, Stremmel W. Lentiviral gene transfer ameliorates disease progression in LongEvans cinnamon rats: an animal model for Wilson disease. Scand J Gastroenterol 2006; 41(8):974-82.

[71] Ha-Hao D, Merle U, Hofmann C, Wesch H, Doll J, Auburger G, et al. Chances and shortcomins of adenovirus-mediated ATP7B gene transfer in Wilson disease: proof of principle demonstrated in a pilot study with LEC rats. Z Gastroenterol 2002; 40(4):209-16.

[72] Provan D, Gribben J. Molecular Haematology. 2nd ed. Malden, Mass.: Blackwell Pub. 2005.

[73] Boelens JJ, Rocha V, Aldenhoven M, Wynn R, O'Meara A, Michel $\mathrm{G}$, et al. Risk factor analysis of outcomes after unrelated cord blood transplantation in patients with hurler syndrome. Biol Blood Marrow Transplant 2009; 15(5):618-25.

[74] Clarke LA, Wraith JE, Beck M, Kolodny EH, Pastores GM, Muenzer J, et al. Long-term efficacy and safety of laronidase in the treatment of mucopolysaccharidosis I. Pediatrics 2009; 123(1):22940.

[75] Ponder KP, Haskins ME. Gene therapy for mucopolysaccharidosis. Expert Opin Biol Ther 2007; 7(9):1333-45.

[76] Aronovich EL, Bell JB, Belur LR, Gunther R, Koniar B, Erickson $\mathrm{DC}$, et al. Prolonged expression of a lysosomal enzyme in mouse liver after Sleeping Beauty transposon-mediated gene delivery: implications for non-viral gene therapy of mucopolysaccharidoses. J Gene Med 2007; 9(5):403-15.

[77] Aronovich EL, Bell JB, Khan SA, Belur LR, Gunther R, Koniar B, et al. Systemic correction of storage disease in MPS I NOD/SCID mice using the sleeping beauty transposon system. Mol Ther 2009; 17(7):1136-44

[78] Liu Y, Xu L, Hennig AK, Kovacs A, Fu A, Chung S, et al. Liverdirected neonatal gene therapy prevents cardiac, bone, ear, and eye disease in mucopolysaccharidosis I mice. Mol Ther 2005; 11(1):3547.

[79] Ma X, Tittiger M, Knutsen RH, Kovacs A, Schaller L, Mecham $\mathrm{RP}$, et al. Upregulation of elastase proteins results in aortic dilatation in mucopolysaccharidosis I mice. Mol Genet Metab 2008; 94(3):298-304.

[80] Ma X, Liu Y, Tittiger M, Hennig A, Kovacs A, Popelka S, et al. Improvements in mucopolysaccharidosis I mice after adult retroviral vector-mediated gene therapy with immunomodulation. Mol Ther 2007; 15(5):889-902.

[81] Metcalf JA, Ma X, Linders B, Wu S, Schambach A, Ohlemiller $\mathrm{KK}$, et al. A self-inactivating gamma-retroviral vector reduces manifestations of mucopolysaccharidosis I in mice. Mol Ther 2010; 18(2):334-42.

[82] Ponder KP, Wang B, Wang P, Ma X, Herati R, Cullen K, et al. Mucopolysaccharidosis I cats mount a cytotoxic $\mathrm{T}$ lymphocyte response after neonatal gene therapy that can be blocked with CTLA4-Ig. Mol Ther 2006; 14(1):5-13.

[83] Traas AM, Wang P, Ma X, Tittiger M, Schaller L, O'Donnell P, et al. Correction of clinical manifestations of canine mucopolysaccharidosis I with neonatal retroviral vector gene therapy. Mol Ther 2007; 15(8):1423-31

[84] Herati RS, Knox VW, O'Donnell P, D'Angelo M, Haskins ME, Ponder KP. Radiographic evaluation of bones and joints in mucopolysaccharidosis I and VII dogs after neonatal gene therapy. Mol Genet Metab 2008; 95(3):142-51.

[85] Hartung SD, Frandsen JL, Pan D, Koniar BL, Graupman P, Gunther $\mathrm{R}$, et al. Correction of metabolic, craniofacial, and neurologic abnormalities in MPS I mice treated at birth with adenoassociated virus vector transducing the human alpha-L-iduronidase gene. Mol Ther 2004; 9(6):866-75.

[86] Kobayashi H, Carbonaro D, Pepper K, Petersen D, Ge S, Jackson $\mathrm{H}$, et al. Neonatal gene therapy of MPS I mice by intravenous injection of a lentiviral vector. Mol Ther 2005; 11(5):776-89.

[87] Di Domenico C, Di Napoli D, Gonzalez YRE, Lombardo A, Naldini L, Di Natale P. Limited transgene immune response and long-term expression of human alpha-L-iduronidase in young adult mice with mucopolysaccharidosis type I by liver-directed gene therapy. Hum Gene Ther 2006; 17(11):1112-21

[88] Litjens T, Hopwood JJ. Mucopolysaccharidosis type VI: Structural and clinical implications of mutations in N-acetylgalactosamine-4sulfatase. Hum Mutat 2001; 18(4):282-95. 
[89] Innes KE, Byers TE. Preeclampsia and breast cancer risk. Epidemiology 1999; 10(6):722-32.

[90] Ho TT, Maguire AM, Aguirre GD, Surace EM, Anand V, Zeng Y, et al. Phenotypic rescue after adeno-associated virus-mediated delivery of 4-sulfatase to the retinal pigment epithelium of feline mucopolysaccharidosis VI. J Gene Med 2002; 4(6):613-21.

[91] Cotugno G, Annunziata P, Tessitore A, O'Malley T, Capalbo A, Faella A, et al. Long-term amelioration of feline Mucopolysaccharidosis VI after AAV-mediated liver gene transfer. Mol Ther 2011; 19(3):461-9.

[92] Slyper AH, Findling JW. Use of a two-site immunoradiometric assay to resolve a factitious elevation of ACTH in primary pigmented nodular adrenocortical disease. J Pediatr Endocrinol 1994; 7(1):61-3.

[93] el Daly ES. Influence of acute and chronic morphine or stadol on the secretion of adrenocorticotrophin and its hypothalamic releasing hormone in the rat. Life Sci 1996; 59(22):1881-90.

[94] Elliger SS, Elliger CA, Lang C, Watson GL. Enhanced secretion and uptake of beta-glucuronidase improves adeno-associated viralmediated gene therapy of mucopolysaccharidosis type VII mice. Mol Ther 2002; 5(5 Pt 1):617-26.

[95] Xu L, Mango RL, Sands MS, Haskins ME, Ellinwood NM, Ponder KP. Evaluation of pathological manifestations of disease in mucopolysaccharidosis VII mice after neonatal hepatic gene therapy. Mol Ther 2002; 6(6):745-58.

[96] Ponder KP, Melniczek JR, Xu L, Weil MA, O'Malley TM, O'Donnell PA, et al. Therapeutic neonatal hepatic gene therapy in mucopolysaccharidosis VII dogs. Proc Natl Acad Sci U S A 2002; 99(20):13102-7.

[97] Xu L, Haskins ME, Melniczek JR, Gao C, Weil MA, O'Malley $\mathrm{TM}$, et al. Transduction of hepatocytes after neonatal delivery of a Moloney murine leukemia virus based retroviral vector results in long-term expression of beta-glucuronidase in mucopolysaccharidosis VII dogs. Mol Ther 2002; 5(2):141-53.

[98] Koeberl DD, Kishnani PS. Immunomodulatory gene therapy in lysosomal storage disorders. Curr Gene Ther 2009; 9(6):503-10.

[99] Sun B, Chen YT, Bird A, Xu F, Hou YX, Amalfitano A, et al. Packaging of an AAV vector encoding human acid alphaglucosidase for gene therapy in glycogen storage disease type II with a modified hybrid adenovirus-AAV vector. Mol Ther 2003; 7(4):467-77.

[100] Sun B, Young SP, Li P, Di C, Brown T, Salva MZ, et al. Correction of multiple striated muscles in murine Pompe disease through adeno-associated virus-mediated gene therapy. Mol Ther 2008; 16(8):1366-71.

[101] Sun B, Kulis MD, Young SP, Hobeika AC, Li S, Bird A, et al. Immunomodulatory gene therapy prevents antibody formation and lethal hypersensitivity reactions in murine pompe disease. Mol Ther 2010; 18(2):353-60.

[102] Grompe M. The pathophysiology and treatment of hereditary tyrosinemia type 1. Semin Liver Dis 2001; 21(4):563-71.

[103] Paulk NK, Wursthorn K, Wang Z, Finegold MJ, Kay MA, Grompe M. Adeno-associated virus gene repair corrects a mouse model of hereditary tyrosinemia in vivo. Hepatology 2010; 51(4):1200-8.

[104] Chen SJ, Tazelaar J, Moscioni AD, Wilson JM. In vivo selection of hepatocytes transduced with adeno-associated viral vectors. Mol Ther 2000; 1(5 Pt 1):414-22.

[105] Overturf K, Al-Dhalimy M, Tanguay R, Brantly M, Ou CN, Finegold M, et al. Hepatocytes corrected by gene therapy are selected in vivo in a murine model of hereditary tyrosinaemia type I. Nat Genet 1996; 12(3):266-73.

[106] Overturf K, Al-Dhalimy M, Manning K, Ou CN, Finegold M, Grompe M. Ex vivo hepatic gene therapy of a mouse model of Hereditary Tyrosinemia Type I. Hum Gene Ther 1998; 9(3):295304.

[107] Overturf K, al-Dhalimy M, Ou CN, Finegold M, Tanguay R, Lieber A, et al. Adenovirus-mediated gene therapy in a mouse model of hereditary tyrosinemia type I. Hum Gene Ther 1997; 8(5):513-21.

[108] Grompe M, Overturf K, al-Dhalimy M, Finegold M. Therapeutic trials in the murine model of hereditary tyrosinaemia type I: a progress report. J Inherit Metab Dis 1998; 21(5):518-31.

[109] Wilber A, Wangensteen KJ, Chen Y, Zhuo L, Frandsen JL, Bell $\mathrm{JB}$, et al. Messenger RNA as a source of transposase for sleeping beauty transposon-mediated correction of hereditary tyrosinemia type I. Mol Ther 2007; 15(7):1280-7.

[110] Montini E, Held PK, Noll M, Morcinek N, Al-Dhalimy M, Finegold M, et al. In vivo correction of murine tyrosinemia type I by DNA-mediated transposition. Mol Ther 2002; 6(6):759-69.

[111] Held PK, Olivares EC, Aguilar CP, Finegold M, Calos MP, Grompe M. In vivo correction of murine hereditary tyrosinemia type I by phiC31 integrase-mediated gene delivery. Mol Ther 2005; 11(3):399-408.

[112] Ranes J, Stoller JK. A review of alpha-1 antitrypsin deficiency. Semin Respir Crit Care Med 2005; 26(2):154-66.

[113] Yusa K, Rashid ST, Strick-Marchand H, Varela I, Liu PQ, Paschon $\mathrm{DE}$, et al. Targeted gene correction of alpha1-antitrypsin deficiency in induced pluripotent stem cells. Nature 2011; 478(7369):391-4.

[114] Bortolussi G, Zentilin L, Baj G, Giraudi P, Bellarosa C, Giacca M, et al. Rescue of bilirubin-induced neonatal lethality in a mouse model of Crigler-Najjar syndrome type I by AAV9-mediated gene transfer. Faseb J 2011.

[115] Birraux J, Menzel O, Wildhaber B, Jond C, Nguyen TH, Chardot C. A step toward liver gene therapy: efficient correction of the genetic defect of hepatocytes isolated from a patient with CriglerNajjar syndrome type 1 with lentiviral vectors. Transplantation 2009; 87(7):1006-12.

[116] van der Wegen P, Louwen R, Imam AM, Buijs-Offerman RM, Sinaasappel M, Grosveld F, et al. Successful treatment of UGT1A1 deficiency in a rat model of Crigler-Najjar disease by intravenous administration of a liver-specific lentiviral vector. Mol Ther 2006; 13(2):374-81.

[117] Kren BT, Parashar B, Bandyopadhyay P, Chowdhury NR, Chowdhury JR, Steer CJ. Correction of the UDPglucuronosyltransferase gene defect in the gunn rat model of crigler-najjar syndrome type I with a chimeric oligonucleotide. Proc Natl Acad Sci U S A 1999; 96(18):10349-54.

[118] Miranda PS, Bosma PJ. Towards liver-directed gene therapy for Crigler-Najjar syndrome. Curr Gene Ther 2009; 9(2):72-82.

[119] Raja NS, Janjua KA. Epidemiology of hepatitis C virus infection in Pakistan. J Microbiol Immunol Infect 2008; 41(1):4-8.

[120] Berenguer M, Lopez-Labrador FX, Wright TL. Hepatitis C and liver transplantation. J Hepatol 2001; 35(5):666-78.

[121] Kendall JZ, Rivera-Alcina ME, Plopper CG, Weir AJ, Randall GC, Saldana-Gautier L. A morphometric study of lung maturation in the adrenocorticotrophin- infused fetal lamb. Biol Neonate 1991; 60(34):258-72.

[122] Ashfaq UA, Yousaf MZ, Aslam M, Ejaz R, Jahan S, Ullah O. siRNAs: potential therapeutic agents against hepatitis $\mathrm{C}$ virus. Virol J 2011; 8:276.

[123] Hsu EC, Hsi B, Hirota-Tsuchihara M, Ruland J, Iorio C, Sarangi F, et al. Modified apoptotic molecule (BID) reduces hepatitis $\mathrm{C}$ virus infection in mice with chimeric human livers. Nat Biotechnol 2003; 21(5):519-25.

[124] Barker LF, Shulman NR, Murray R, Hirschman RJ, Ratner F, Diefenbach WC, et al. Transmission of serum hepatitis. 1970. JAMA 1996; 276(10):841-4.

[125] Li Z, Yao H, Ma Y, Dong Q, Chen Y, Peng Y, et al. Inhibition of HBV gene expression and replication by stably expressed interferon-alpha1 via adeno-associated viral vectors. J Gene Med 2008; 10(6):619-27.

[126] Ebert G, Poeck H, Lucifora J, Baschuk N, Esser K, Esposito I, et al. 5' Triphosphorylated small interfering RNAs control replication of hepatitis B virus and induce an interferon response in human liver cells and mice. Gastroenterology 2011; 141(2):696-706, e1-3.

[127] Disdier M, Morrissey JH, Fugate RD, Bainton DF, McEver RP. Cytoplasmic domain of P-selectin (CD62) contains the signal for sorting into the regulated secretory pathway. Mol Biol Cell 1992; 3(3):309-21.

[128] Rottinghaus ST, Poland GA, Jacobson RM, Barr LJ, Roy MJ. Hepatitis B DNA vaccine induces protective antibody responses in human non-responders to conventional vaccination. Vaccine 2003; 21(31):4604-8.

[129] Lang Kuhs KA, Ginsberg AA, Yan J, Wiseman RW, Khan AS, Sardesai NY, et al. Hepatitis C Virus NS3/NS3A DNA Vaccine Induces Multiepitope $\mathrm{T}$ Cell Responses in Rhesus Macaques Mimicking Human Immune Responses. Mol Ther 2011; 20(3):66978. 
[130] Zhou C, Peng G, Jin X, Tang J, Chen Z. Vaccination with a fusion DNA vaccine encoding hepatitis $B$ surface antigen fused to the extracellular domain of CTLA4 enhances HBV-specific immune responses in mice: implication of its potential use as a therapeutic vaccine. Clin Immunol 2010; 137(2):190-8.

[131] Tozawa Y, Ueki A, Manabe S, Matsushima K. Stress-induced increase in urinary isatin excretion in rats: reversal by both dexamethasone and alpha-methyl-P-tyrosine. Biochem Pharmacol 1998; 56(8):1041-6.

[132] Nakamura T, Sakata R, Ueno T, Sata M, Ueno H. Inhibition of transforming growth factor beta prevents progression of liver fibrosis and enhances hepatocyte regeneration in dimethylnitrosamine-treated rats. Hepatology 2000; 32(2):247-55.

[133] Qi Z, Atsuchi N, Ooshima A, Takeshita A, Ueno H. Blockade of type beta transforming growth factor signaling prevents liver fibrosis and dysfunction in the rat. Proc Natl Acad Sci U S A 1999; 96(5):2345-9.

[134] Ueno H, Sakamoto T, Nakamura T, Qi Z, Astuchi N, Takeshita A, et al. A soluble transforming growth factor beta receptor expressed in muscle prevents liver fibrogenesis and dysfunction in rats. Hum Gene Ther 2000; 11(1):33-42.

[135] Kingston PA, Sinha S, David A, Castro MG, Lowenstein PR, Heagerty AM. Adenovirus-mediated gene transfer of a secreted transforming growth factor-beta type II receptor inhibits luminal loss and constrictive remodeling after coronary angioplasty and enhances adventitial collagen deposition. Circulation 2001; 104(21):2595-601.

[136] Jiang W, Yang CQ, Liu WB, Wang YQ, He BM, Wang JY. Blockage of transforming growth factor beta receptors prevents progression of pig serum-induced rat liver fibrosis. World $\mathrm{J}$ Gastroenterol 2004; 10(11):1634-8.

[137] Nakamura H, Siddiqui SS, Shen X, Malik AB, Pulido JS, Kumar $\mathrm{NM}$, et al. RNA interference targeting transforming growth factorbeta type II receptor suppresses ocular inflammation and fibrosis. Mol Vis 2004; 10:703-11.

[138] Dooley S, Hamzavi J, Breitkopf K, Wiercinska E, Said HM, Lorenzen J, et al. Smad7 prevents activation of hepatic stellate cells and liver fibrosis in rats. Gastroenterology 2003; 125(1):178-91.

[139] Terada Y, Hanada S, Nakao A, Kuwahara M, Sasaki S, Marumo F. Gene transfer of Smad7 using electroporation of adenovirus prevents renal fibrosis in post-obstructed kidney. Kidney Int 2002; 61(1 Suppl):S94-8.

[140] Hou CC, Wang W, Huang XR, Fu P, Chen TH, Sheikh-Hamad D, et al. Ultrasound-microbubble-mediated gene transfer of inducible Smad7 blocks transforming growth factor-beta signaling and fibrosis in rat remnant kidney. Am J Pathol 2005; 166(3):761-71.

[141] Song YH, Chen XL, Kong XJ, Liu NZ, Li W, Wu XL, et al. Ribozymes against TGFbeta1 reverse character of activated hepatic stellate cells in vitro and inhibit liver fibrosis in rats. J Gene Med 2005; 7(7):965-76.

[142] Sanderson N, Factor V, Nagy P, Kopp J, Kondaiah P, Wakefield L, et al. Hepatic expression of mature transforming growth factor beta 1 in transgenic mice results in multiple tissue lesions. Proc Natl Acad Sci U S A 1995; 92(7):2572-6.

[143] Imai E, Isaka Y, Fujiwara Y, Kaneda Y, Kamada T, Ueda N. Introduction of a foreign gene into the kidney in vivo: development of glomerulosclerosis by the transfection of genes for PDGF and TGF-beta. Contrib Nephrol 1994; 107:205-15.

[144] Cone RD, Lu D, Koppula S, Vage DI, Klungland H, Boston B, et al. The melanocortin receptors: agonists, antagonists, and the hormonal control of pigmentation. Recent Prog Horm Res 1996; 51:287-317.

[145] Arias M, Lahme B, Van de Leur E, Gressner AM, Weiskirchen R. Adenoviral delivery of an antisense RNA complementary to the 3' coding sequence of transforming growth factor-betal inhibits fibrogenic activities of hepatic stellate cells. Cell Growth Differ 2002; 13(6):265-73.

[146] Arias M, Sauer-Lehnen S, Treptau J, Janoschek N, Theuerkauf I, Buettner R, et al. Adenoviral expression of a transforming growth factor-betal antisense mRNA is effective in preventing liver fibrosis in bile-duct ligated rats. BMC Gastroenterol 2003; 3:29.

[147] Santama N, Li KW, Bright KE, Yeoman M, Geraerts WP, Benjamin PR, et al. Processing of the FMRFamide precursor protein in the snail Lymnaea stagnalis: characterization and neuronal localization of a novel peptide, 'SEEPLY'. Eur J Neurosci 1993; 5(8):1003-16.

[148] Zhang G, Wang Q, Xu R. Therapeutics Based on microRNA: A New Approach for Liver Cancer. Curr Genomics 2010; 11(5):31125.

[149] Sun Y, Qian C, Peng D, Prieto J. Gene transfer to liver cancer cells of B7-1 plus interleukin 12 changes immunoeffector mechanisms and suppresses helper $\mathrm{T}$ cell type 1 cytokine production induced by interleukin 12 alone. Hum Gene Ther 2000; 11(1):127-38.

[150] Llovet JM, Sala M, Castells L, Suarez Y, Vilana R, Bianchi L, et al. Randomized controlled trial of interferon treatment for advanced hepatocellular carcinoma. Hepatology 2000; 31(1):54-8.

[151] Patt YZ, Hassan MM, Lozano RD, Brown TD, Vauthey JN, Curley $\mathrm{SA}$, et al. Phase II trial of systemic continuous fluorouracil and subcutaneous recombinant interferon Alfa-2b for treatment of hepatocellular carcinoma. J Clin Oncol 2003; 21(3):421-7.

[152] Lin AY, Brophy N, Fisher GA, So S, Biggs C, Yock TI, et al. Phase II study of thalidomide in patients with unresectable hepatocellular carcinoma. Cancer 2005;103(1):119-25.

[153] Patt YZ, Hassan MM, Lozano RD, Nooka AK, Schnirer, II, Zeldis $\mathrm{JB}$, et al. Thalidomide in the treatment of patients with hepatocellular carcinoma: a phase II trial. Cancer 2005; 103(4):749-55.

[154] Zhu AX, Fuchs CS, Clark JW, Muzikansky A, Taylor K, Sheehan $\mathrm{S}$, et al. A phase II study of epirubicin and thalidomide in unresectable or metastatic hepatocellular carcinoma. Oncologist 2005; 10(6):392-8.

[155] Philip PA, Mahoney MR, Allmer C, Thomas J, Pitot HC, Kim G, et al. Phase II study of Erlotinib (OSI-774) in patients with advanced hepatocellular cancer. J Clin Oncol 2005; 23(27):6657-63.

[156] Thomas MB, Chadha R, Glover K, Wang X, Morris J, Brown T, et al. Phase 2 study of erlotinib in patients with unresectable hepatocellular carcinoma. Cancer 2007; 110(5):1059-67.

[157] Lassau N, Koscielny S, Chami L, Chebil M, Benatsou B, Roche A, et al. Advanced hepatocellular carcinoma: early evaluation of response to bevacizumab therapy at dynamic contrast-enhanced US with quantification--preliminary results. Radiology 2011; 258(1):291-300.

[158] Zhu AX, Stuart K, Blaszkowsky LS, Muzikansky A, Reitberg DP, Clark JW, et al. Phase 2 study of cetuximab in patients with advanced hepatocellular carcinoma. Cancer 2007; 110(3):581-9.

[159] Uckun FM, Sudbeck EA, Mao C, Ghosh S, Liu XP, Vassilev AO, et al. Structure-based design of novel anticancer agents. Curr Cancer Drug Targets 2001; 1(1):59-71.

[160] Zhang ZL, Zou WG, Luo CX, Li BH, Wang JH, Sun LY, et al. An armed oncolytic adenovirus system, ZD55-gene, demonstrating potent antitumoral efficacy. Cell Res 2003; 13(6):481-9.

[161] Gan Y, Gu J, Cai X, Hu J, Liu XY, Zhao X. Adenovirus-mediated HCCS1 overexpression elicits a potent antitumor efficacy on human colorectal cancer and hepatoma cells both in vitro and in vivo. Cancer Gene Ther 2008; 15(12):808-16.

[162] Wei RC, Cao X, Gui JH, Zhou XM, Zhong D, Yan QL, et al. Augmenting the antitumor effect of TRAIL by SOCS3 with double-regulated replicating oncolytic adenovirus in hepatocellular carcinoma. Hum Gene Ther 2011; 22(9):1109-19.

[163] Xue B, Moustaid N, Wilkison WO, Zemel MB. The agouti gene product inhibits lipolysis in human adipocytes via a $\mathrm{Ca} 2+-$ dependent mechanism. Faseb J 1998; 12(13):1391-6.

[164] Fang YX, Zhang XB, Wei W, Liu YW, Chen JZ, Xue JL, et al. Development of chimeric gene regulators for cancer-specific gene therapy with both transcriptional and translational targeting. Mol Biotechnol 2010; 45(1):71-81.

[165] Sagawa T, Yamada Y, Takahashi M, Sato Y, Kobune M, Takimoto $\mathrm{R}$, et al. Treatment of hepatocellular carcinoma by AdAFPep/rep, AdAFPep/p53, and 5-fluorouracil in mice. Hepatology 2008; 48(3):828-40.

[166] Hsieh YJ, Liu RS, Hwu L, Ke CC, Wang FH, Wang HE, et al. Cre/loxP system controlled by specific promoter for radiationmediated gene therapy of hepatoma. Anticancer Res 2007; 27(3B):1571-9.

[167] Lambropoulou M, Stefanou D, Alexiadis G, Tamiolakis D, Tripsianis G, Chatzaki E, et al. Cytoplasmic expression of c-erb-B2 in endometrial carcinomas. Onkologie 2007; 30(10):495-500. 
[168] Foka P, Pourchet A, Hernandez-Alcoceba R, Doumba PP, Pissas G, Kouvatsis $\mathrm{V}$, et al. Novel tumour-specific promoters for transcriptional targeting of hepatocellular carcinoma by herpes simplex virus vectors. J Gene Med 2010; 12(12):956-67.

[169] Lee TK, Han JS, Fan ST, Liang ZD, Tian PK, Gu JR, et al. Gene delivery using a receptor-mediated gene transfer system targeted to hepatocellular carcinoma cells. Int J Cancer 2001; 93(3):393-400.

[170] Sia KC, Huynh H, Chinnasamy N, Hui KM, Lam PY. Suicidal gene therapy in the effective control of primary human hepatocellular carcinoma as monitored by noninvasive bioimaging. Gene Ther 2011; 19(5):532-42.

[171] Argnani R, Marconi P, Volpi I, Bolanos E, Carro E, Ried C, et al. Characterization of herpes simplex virus 1 strains as platforms for the development of oncolytic viruses against liver cancer. Liver Int 2011; 31(10):1542-53.

[172] Song TJ, Eisenberg DP, Adusumilli PS, Hezel M, Fong Y. Oncolytic herpes viral therapy is effective in the treatment of hepatocellular carcinoma cell lines. J Gastrointest Surg 2006; 10(4):532-42.

[173] Wills KN, Huang WM, Harris MP, Machemer T, Maneval DC, Gregory RJ. Gene therapy for hepatocellular carcinoma: chemosensitivity conferred by adenovirus-mediated transfer of the HSV-1 thymidine kinase gene. Cancer Gene Ther 1995; 2(3):1917.

[174] Iwai M, Harada Y, Tanaka S, Muramatsu A, Mori T, Kashima K, et al. Polyethylenimine-mediated suicide gene transfer induces a therapeutic effect for hepatocellular carcinoma in vivo by using an Epstein-Barr virus-based plasmid vector. Biochem Biophys Res Commun 2002; 291(1):48-54.

[175] Harada Y, Iwai M, Tanaka S, Okanoue T, Kashima K, MaruyamaTabata $\mathrm{H}$, et al. Highly efficient suicide gene expression in hepatocellular carcinoma cells by epstein-barr virus-based plasmid vectors combined with polyamidoamine dendrimer. Cancer Gene Ther 2000; 7(1):27-36.

[176] Maruyama-Tabata H, Harada Y, Matsumura T, Satoh E, Cui F, Iwai $\mathrm{M}$, et al. Effective suicide gene therapy in vivo by EBV-based plasmid vector coupled with polyamidoamine dendrimer. Gene Ther 2000; 7(1):53-60.

[177] Kanai F, Lan KH, Shiratori Y, Tanaka T, Ohashi M, Okudaira T, et al. In vivo gene therapy for alpha-fetoprotein-producing hepatocellular carcinoma by adenovirus-mediated transfer of cytosine deaminase gene. Cancer Res 1997; 57(3):461-5.

[178] Xu HN, Huang WD, Cai Y, Ding M, Gu JF, Wei N, et al. HCCS1armed, quadruple-regulated oncolytic adenovirus specific for liver cancer as a cancer targeting gene-viro-therapy strategy. Mol Cancer $2011 ; 10: 133$

[179] Takahashi M, Sato T, Sagawa T, Lu Y, Sato Y, Iyama S, et al. E1B-55K-deleted adenovirus expressing E1A-13S by AFPenhancer/promoter is capable of highly specific replication in AFPproducing hepatocellular carcinoma and eradication of established tumor. Mol Ther 2002; 5(5 Pt 1):627-34.

[180] Kanai F. Transcriptional targeted gene therapy for hepatocellular carcinoma by adenovirus vector. Mol Biotechnol 2001; 18(3):24350 .

[181] Guan YS, La Z, Yang L, He Q, Li P. p53 gene in treatment of hepatic carcinoma: status quo. World J Gastroenterol 2007; 13(7):985-92.

[182] Chen W, Wu Y, Liu W, Wang G, Wang X, Yang Y, et al. Enhanced antitumor efficacy of a novel fiber chimeric oncolytic adenovirus expressing p53 on hepatocellular carcinoma. Cancer Lett 2011;307(1):93-103.

[183] Inoue H, Shiraki K, Murata K, Sugimoto K, Kawakita T, Yamaguchi Y, et al. Adenoviral-mediated transfer of p53 gene enhances TRAIL-induced apoptosis in human hepatocellular carcinoma cells. Int J Mol Med 2004; 14(2):271-5.

[184] Gu T, Li CX, Feng Y, Wang Q, Li CH, Li CF. Trans-arterial gene therapy for hepatocellular carcinoma in a rabbit model. World $\mathrm{J}$ Gastroenterol 2007; 13(14):2113-7.

[185] Song LP, Li YP, Qiu SD. [Construction and antitumor effect of recombinant adenovirus vector containing heterofusion gene NT4p53(N15)Ant]. Ai Zheng 2008; 27(2):144-8.

[186] Wang X, Ye Z, Zhong J, Xiang J, Yang J. Adenovirus-mediated Il24 expression suppresses hepatocellular carcinoma growth via induction of cell apoptosis and cycling arrest and reduction of angiogenesis. Cancer Biother Radiopharm 2007; 22(1):56-63.

[187] Guo Y, Zeng Y, Wang K, Zhu X, Luo H, Zheng M, et al. [Therapeutic potential of recombinant adenovirus expressing p53 in hepatocellular carcinoma cell lines]. Zhonghua Gan Zang Bing Za Zhi 2001; 9 Suppl:43-5.

[188] Ohashi M, Kanai F, Tateishi K, Taniguchi H, Marignani PA, Yoshida $\mathrm{Y}$, et al. Target gene therapy for alpha-fetoproteinproducing hepatocellular carcinoma by E1B55k-attenuated adenovirus. Biochem Biophys Res Commun 2001; 282(2):529-35.

[189] Habib N, Salama H, Abd El Latif Abu Median A, Isac Anis I, Abd Al Aziz RA, Sarraf C, et al. Clinical trial of E1B-deleted adenovirus (d11520) gene therapy for hepatocellular carcinoma. Cancer Gene Ther 2002; 9(3):254-9.

[190] Yang ZX, Wang D, Wang G, Zhang QH, Liu JM, Peng P, et al. Clinical study of recombinant adenovirus-p53 combined with fractionated stereotactic radiotherapy for hepatocellular carcinoma. J Cancer Res Clin Oncol 2010; 136(4):625-30.

[191] Tian G, Liu J, Sui J. A patient with huge hepatocellular carcinoma who had a complete clinical response to p53 gene combined with chemotherapy and transcatheter arterial chemoembolization. Anticancer Drugs 2009; 20(5):403-7.

[192] Tian G, Liu J, Zhou JS, Chen W. Multiple hepatic arterial injections of recombinant adenovirus p53 and 5-fluorouracil after transcatheter arterial chemoembolization for unresectable hepatocellular carcinoma: a pilot phase II trial. Anticancer Drugs 2009; 20(5):389-95.

[193] Guan YS, Liu Y, Sun L, Li X, He Q. Successful management of postoperative recurrence of hepatocellular carcinoma with p53 gene therapy combining transcatheter arterial chemoembolization. World J Gastroenterol 2005; 11(24):3803-5.

[194] Berzofsky JA, Terabe M, Oh S, Belyakov IM, Ahlers JD, Janik JE, et al. Progress on new vaccine strategies for the immunotherapy and prevention of cancer. J Clin Invest 2004; 113(11):1515-25.

[195] Gilboa E. The promise of cancer vaccines. Nat Rev Cancer 2004; 4(5):401-11.

[196] Matar P, Alaniz L, Rozados V, Aquino JB, Malvicini M, Atorrasagasti $\mathrm{C}$, et al. Immunotherapy for liver tumors: present status and future prospects. J Biomed Sci 2009; 16:30.

[197] Trinchieri G. Interleukin-12 and the regulation of innate resistance and adaptive immunity. Nat Rev Immunol 2003; 3(2):133-46.

[198] Colombo MP, Trinchieri G. Interleukin-12 in anti-tumor immunity and immunotherapy. Cytokine Growth Factor Rev 2002; 13(2):155-68.

[199] Angiolillo AL, Sgadari C, Taub DD, Liao F, Farber JM, Maheshwari S, et al. Human interferon-inducible protein 10 is a potent inhibitor of angiogenesis in vivo. J Exp Med 1995; 182(1):155-62.

[200] Mazzolini G, Narvaiza I, Bustos M, Duarte M, Tirapu I, Bilbao R, et al. Alpha(v)beta(3) integrin-mediated adenoviral transfer of interleukin-12 at the periphery of hepatic colon cancer metastases induces VCAM-1 expression and T-cell recruitment. Mol Ther 2001; 3(5 Pt 1):665-72.

[201] Leonard JP, Sherman ML, Fisher GL, Buchanan LJ, Larsen G, Atkins MB, et al. Effects of single-dose interleukin-12 exposure on interleukin-12-associated toxicity and interferon-gamma production. Blood 1997; 90(7):2541-8.

[202] Mazzolini G, Prieto J, Melero I. Gene therapy of cancer with interleukin-12. Curr Pharm Des 2003; 9(24):1981-91.

[203] Adris S, Klein S, Jasnis M, Chuluyan E, Ledda M, Bravo A, et al. IL-10 expression by CT26 colon carcinoma cells inhibits their malignant phenotype and induces a $\mathrm{T}$ cell-mediated tumor rejection in the context of a systemic Th2 response. Gene Ther 1999; 6(10):1705-12.

[204] Mazzolini G, Qian C, Xie X, Sun Y, Lasarte JJ, Drozdzik M, et al. Regression of colon cancer and induction of antitumor immunity by intratumoral injection of adenovirus expressing interleukin-12. Cancer Gene Ther 1999; 6(6):514-22.

[205] Adris S, Chuluyan E, Bravo A, Berenstein M, Klein S, Jasnis M, et al. Mice vaccination with interleukin 12-transduced colon cancer cells potentiates rejection of syngeneic non-organ-related tumor cells. Cancer Res 2000; 60(23):6696-703.

[206] Barajas M, Mazzolini G, Genove G, Bilbao R, Narvaiza I, Schmitz $\mathrm{V}$, et al. Gene therapy of orthotopic hepatocellular carcinoma in 
rats using adenovirus coding for interleukin 12. Hepatology 2001; 33(1):52-61.

[207] Mazzolini G, Qian C, Narvaiza I, Barajas M, Borras-Cuesta F, Xie $\mathrm{X}$, et al. Adenoviral gene transfer of interleukin 12 into tumors synergizes with adoptive $\mathrm{T}$ cell therapy both at the induction and effector level. Hum Gene Ther 2000; 11(1):113-25.

[208] Lanzone A, Guido M, Ciampelli M, Fulghesu AM, Pavone V, Proto $\mathrm{C}$, et al. Evidence of a disturbance of the hypothalamicpituitary-adrenal axis in polycystic ovary syndrome: effect of naloxone. Clin Endocrinol (Oxf) 1996; 45(1):73-7.

[209] Putzer BM, Stiewe T, Rodicker F, Schildgen O, Ruhm S, Dirsch O, et al. Large nontransplanted hepatocellular carcinoma in woodchucks: treatment with adenovirus-mediated delivery of interleukin 12/B7.1 genes. J Natl Cancer Inst 2001; 93(6):472-9.

[210] Mazzolini G, Narvaiza I, Perez-Diez A, Rodriguez-Calvillo M, Qian C, Sangro B, et al. Genetic heterogeneity in the toxicity to systemic adenoviral gene transfer of interleukin-12. Gene Ther 2001; 8(4):259-67

[211] Narvaiza I, Mazzolini G, Barajas M, Duarte M, Zaratiegui M, Qian $\mathrm{C}$, et al. Intratumoral coinjection of two adenoviruses, one encoding the chemokine IFN-gamma-inducible protein-10 and another encoding IL-12, results in marked antitumoral synergy. J Immunol 2000; 164(6):3112-22.

[212] Elman I, Adler CM, Malhotra AK, Bir C, Pickar D, Breier A. Effect of acute metabolic stress on pituitary-adrenal axis activation in patients with schizophrenia. Am J Psychiatry 1998; 155(7):97981.

[213] Bischoff JR, Kirn DH, Williams A, Heise C, Horn S, Muna M, et al. An adenovirus mutant that replicates selectively in p53-deficient human tumor cells. Science 1996; 274(5286):373-6.

[214] Hamid O, Varterasian ML, Wadler S, Hecht JR, Benson A 3rd, Galanis E, et al. Phase II trial of intravenous CI-1042 in patients with metastatic colorectal cancer. J Clin Oncol 2003; 21(8):1498504.

[215] Hernandez-Alcoceba R, Sangro B, Prieto J. Gene therapy of liver cancer. Ann Hepatol 2007; 6(1):5-14.

[216] Sun XY, Wu ZD, Hu JB. Suicide gene therapy of hepatocellular carcinoma and delivery procedure and route of therapeutic gene in vivo. Hepatobiliary Pancreat Dis Int 2002; 1(3):373-7.

[217] Negrini M, Gramantieri L, Sabbioni S, Croce CM. microRNA involvement in hepatocellular carcinoma. Anticancer Agents Med Chem 2011; 11(6):500-21.

[218] Budhu A, Ji J, Wang XW. The clinical potential of microRNAs. J Hematol Oncol 2010; 3:37.

[219] Lu J, Getz G, Miska EA, Alvarez-Saavedra E, Lamb J, Peck D, et al. MicroRNA expression profiles classify human cancers. Nature 2005; 435(7043):834-8

[220] Volinia S, Galasso M, Sana ME, Wise TF, Palatini J, Huebner K, et $a l$. Breast cancer signatures for invasiveness and prognosis defined by deep sequencing of microRNA. Proc Natl Acad Sci U S A 2012; 109(8):3024-9.

[221] Li D, Liu X, Lin L, Hou J, Li N, Wang C, et al. MicroRNA-99a inhibits hepatocellular carcinoma growth and correlates with prognosis of patients with hepatocellular carcinoma. J Biol Chem 2011; 286(42):36677-85.

[222] Law PT, Wong N. Emerging roles of microRNA in the intracellular signaling networks of hepatocellular carcinoma. J Gastroenterol Hepatol 2011; 26(3):437-49.

[223] Grosshans H, Bussing I. MicroRNA biogenesis takes another single hit from microsatellite instability. Cancer Cell 2010; 18(4):295-7.

[224] de Koning HP, Jenks BG, Huchede B, Roubos EW. Dynamics of cyclic-AMP efflux in relation to alpha-MSH secretion from melanotrope cells of Xenopus laevis. Life Sci 1992; 51(21):166773.

[225] Xiangji L, Feng X, Qingbao C, Weifeng T, Xiaoqing J, Baihe Z, et al. Knockdown of HBV surface antigen gene expression by a lentiviral microRNA-based system inhibits HBV replication and HCC growth. J Viral Hepat 2011; 18(9):653-60.

[226] Li W, Xie L, He X, Li J, Tu K, Wei L, et al. Diagnostic and prognostic implications of microRNAs in human hepatocellular carcinoma. Int J Cancer 2008; 123(7):1616-22.

[227] Gramantieri L, Fornari F, Callegari E, Sabbioni S, Lanza G, Croce $\mathrm{CM}$, et al. MicroRNA involvement in hepatocellular carcinoma. J Cell Mol Med 2008; 12(6A):2189-204.
[228] Jiang J, Gusev Y, Aderca I, Mettler TA, Nagorney DM, Brackett DJ, et al. Association of MicroRNA expression in hepatocellular carcinomas with hepatitis infection, cirrhosis, and patient survival. Clin Cancer Res 2008; 14(2):419-27.

[229] Calin GA, Ferracin M, Cimmino A, di Leva G, Shimizu M, Wojcik $\mathrm{SE}$, et al. A MicroRNA signature associated with prognosis and progression in chronic lymphocytic leukemia. N Engl J Med 2005; 353(17):1793-801.

[230] Jin H, Lv S, Yang J, Wang X, Hu H, Su C, et al. Use of microRNA Let-7 to control the replication specificity of oncolytic adenovirus in hepatocellular carcinoma cells. PLoS One 2011; 6(7):e21307.

[231] Xu Y, Xia F, Ma L, Shan J, Shen J, Yang Z, et al. MicroRNA-122 sensitizes $\mathrm{HCC}$ cancer cells to adriamycin and vincristine through modulating expression of MDR and inducing cell cycle arrest. Cancer Lett 2011;310(2):160-9.

[232] Fang JH, Zhou HC, Zeng C, Yang J, Liu Y, Huang X, et al. MicroRNA-29b suppresses tumor angiogenesis, invasion, and metastasis by regulating matrix metalloproteinase 2 expression. Hepatology 2011; 54(5):1729-40.

[233] Yang F, Zhang L, Wang F, Wang Y, Huo XS, Yin YX, et al. Modulation of the unfolded protein response is the core of microRNA-122-involved sensitivity to chemotherapy in hepatocellular carcinoma. Neoplasia 2011; 13(7):590-600.

[234] Luk JM, Burchard J, Zhang C, Liu AM, Wong KF, Shek FH, et al. DLK1-DIO3 genomic imprinted microRNA cluster at $14 \mathrm{q} 32.2$ defines a stemlike subtype of hepatocellular carcinoma associated with poor survival. J Biol Chem 2011; 286(35):30706-13.

[235] Zhou C, Liu J, Li Y, Liu L, Zhang X, Ma CY, et al. microRNA$1274 \mathrm{a}$, a modulator of sorafenib induced a disintegrin and metalloproteinase 9 (ADAM9) down-regulation in hepatocellular carcinoma. FEBS Lett 2011; 585(12):1828-34.

[236] Ishida T, Yokoyama H, Sugio K, Kaneko S, Sugimachi K, Hara N, et al. Carcinoid tumor of the lung: clinicopathological and immunohistochemical studies. Eur J Surg Oncol 1992; 18(2):180-7.

[237] Filipowicz W, Grosshans H. The liver-specific microRNA miR122: biology and therapeutic potential. Prog Drug Res 2011; 67:221-38

[238] Zhang J, Yang Y, Yang T, Liu Y, Li A, Fu S, et al. microRNA-22, downregulated in hepatocellular carcinoma and correlated with prognosis, suppresses cell proliferation and tumourigenicity. Br J Cancer 2010; 103(8):1215-20.

[239] Young DD, Connelly CM, Grohmann C, Deiters A. Small molecule modifiers of microRNA miR-122 function for the treatment of hepatitis $\mathrm{C}$ virus infection and hepatocellular carcinoma. J Am Chem Soc 2010; 132(23):7976-81.

[240] Fornari F, Milazzo M, Chieco P, Negrini M, Calin GA, Grazi GL, et al. MiR-199a-3p regulates mTOR and c-Met to influence the doxorubicin sensitivity of human hepatocarcinoma cells. Cancer Res 2010; 70(12):5184-93

[241] Shimizu S, Takehara T, Hikita H, Kodama T, Miyagi T, Hosui A, et al. The let-7 family of microRNAs inhibits Bcl-xL expression and potentiates sorafenib-induced apoptosis in human hepatocellular carcinoma. J Hepatol 2010; 52(5):698-704

[242] Liu AM, Poon RT, Luk JM. MicroRNA-375 targets Hipposignaling effector YAP in liver cancer and inhibits tumor properties. Biochem Biophys Res Commun 2010; 394(3):623-7.

[243] Ma L, Liu J, Shen J, Liu L, Wu J, Li W, et al. Expression of miR122 mediated by adenoviral vector induces apoptosis and cell cycle arrest of cancer cells. Cancer Biol Ther 2010; 9(7):554-61.

[244] Xiong Y, Fang JH, Yun JP, Yang J, Zhang Y, Jia WH, et al. Effects of microRNA-29 on apoptosis, tumorigenicity, and prognosis of hepatocellular carcinoma. Hepatology 2010; 51(3):836-45.

[245] Kota J, Chivukula RR, O'Donnell KA, Wentzel EA, Montgomery $\mathrm{CL}$, Hwang HW, et al. Therapeutic microRNA delivery suppresses tumorigenesis in a murine liver cancer model. Cell 2009; 137(6):1005-17.

[246] Xu T, Zhu Y, Xiong Y, Ge YY, Yun JP, Zhuang SM. MicroRNA195 suppresses tumorigenicity and regulates G1/S transition of human hepatocellular carcinoma cells. Hepatology 2009; 50(1):113-21.

[247] Su H, Yang JR, Xu T, Huang J, Xu L, Yuan Y, et al. MicroRNA101, down-regulated in hepatocellular carcinoma, promotes 
apoptosis and suppresses tumorigenicity. Cancer Res 2009; 69(3):1135-42.

[248] Suzuki T, Sakurai F, Nakamura S, Kouyama E, Kawabata K, Kondoh M, et al. miR-122a-regulated expression of a suicide gene prevents hepatotoxicity without altering antitumor effects in suicide gene therapy. Mol Ther 2008; 16(10):1719-26.

[249] Arbuthnot P, Thompson LJ. Harnessing the RNA interference pathway to advance treatment and prevention of hepatocellular carcinoma. World J Gastroenterol 2008; 14(11):1670-81.

[250] Varnholt H, Drebber U, Schulze F, Wedemeyer I, Schirmacher P, Dienes HP, et al. MicroRNA gene expression profile of hepatitis C virus-associated hepatocellular carcinoma. Hepatology 2008; 47(4):1223-32.

[251] Zhang B, Pan X, Cobb GP, Anderson TA. microRNAs as oncogenes and tumor suppressors. Dev Biol 2007; 302(1):1-12.

[252] Niess H, Bao Q, Conrad C, Zischek C, Notohamiprodjo M, Schwab $\mathrm{F}$, et al. Selective targeting of genetically engineered mesenchymal stem cells to tumor stroma microenvironments using tissue-specific suicide gene expression suppresses growth of hepatocellular carcinoma. Ann Surg 2011; 254(5):767-74; discussion 74-5.

[253] Xing Z, Li J, Wang M, Wang G, An S, Yu D. [The relationship between the density of house dust mite allergens in bedroom and the attacks of allergic rhinitis]. Lin Chuang Er Bi Yan Hou Ke Za Zhi 2003; 17(9):547-9.

[254] Acharya SK, Panda SK, Saxena A, Gupta SD. Acute hepatic failure in India: a perspective from the East. J Gastroenterol Hepatol 2000; 15(5):473-9.

[255] Sass DA, Shakil AO. Fulminant hepatic failure. Liver Transpl 2005; 11(6):594-605.

[256] Stockert RJ. The asialoglycoprotein receptor: relationships between structure, function, and expression. Physiol Rev 1995; 75(3):591609.

[257] Singhal S, Chakravarty A, Das BC, Kar P. Tumour necrosis factoralpha and soluble Fas ligand as biomarkers in non-acetaminopheninduced acute liver failure. Biomarkers 2009; 14(5):347-53.

[258] Song E, Lee SK, Wang J, Ince N, Ouyang N, Min J, et al. RNA interference targeting Fas protects mice from fulminant hepatitis. Nat Med 2003; 9(3):347-51.
[259] Streetz K, Leifeld L, Grundmann D, Ramakers J, Eckert K, Spengler U, et al. Tumor necrosis factor alpha in the pathogenesis of human and murine fulminant hepatic failure. Gastroenterology 2000; 119(2):446-60.

[260] Dong L, Zuo L, Xia S, Gao S, Zhang C, Chen J, et al. Reduction of liver tumor necrosis factor-alpha expression by targeting delivery of antisense oligonucleotides into Kupffer cells protects rats from fulminant hepatitis. J Gene Med 2009; 11(3):229-39.

[261] Mundt B, Kuhnel F, Zender L, Paul Y, Tillmann H, Trautwein C, et al. Involvement of TRAIL and its receptors in viral hepatitis. FASEB journal : official publication of the Federation of American Societies for Experimental Biology 2003; 17(1):94-6.

[262] Liu YG, Liu SX, Liang XH, Zhang Q, Gao LF, Han LH, et al. Blockade of TRAIL pathway ameliorates HBV-induced hepatocyte apoptosis in an acute hepatitis model. Biochem Biophys Res Commun 2007; 352(2):329-34.

[263] Opipari AW, Jr., Boguski MS, Dixit VM. The A20 cDNA induced by tumor necrosis factor alpha encodes a novel type of zinc finger protein. J Biol Chem 1990; 265(25):14705-8.

[264] Mizuguchi Y, Yokomuro S, Mishima T, Arima Y, Shimizu T, Kawahigashi $\mathrm{Y}$, et al. Short hairpin RNA modulates transforming growth factor beta signaling in life-threatening liver failure in mice. Gastroenterology 2005; 129(5):1654-62.

[265] Leu JI, Crissey MA, Taub R. Massive hepatic apoptosis associated with TGF-beta1 activation after Fas ligand treatment of IGF binding protein-1-deficient mice. J Clin Invest 2003; 111(1):12939.

[266] Zhu C, Sun Y, Luo X, Yan W, Xi D, Ning Q. Novel mfgl2 antisense plasmid inhibits murine fgl2 expression and ameliorates murine hepatitis virus type 3-induced fulminant hepatitis in BALB/cJ mice. Hum Gene Ther 2006; 17(6):589-600.

[267] Takahashi T, Togo S, Kumamoto T, Watanabe K, Kubota T, Ichikawa $\mathrm{Y}$, et al. Transfection of NF-kappaB decoy oligodeoxynucleotides into macrophages reduces murine fatal liver failure after excessive hepatectomy. J Surg Res 2009; 154(2):17986.

[268] Zhu CL, Li YW, Gao RT. Gene therapy for acute liver failure. Curr Gene Ther 2010; 10(2):156-66. 